IRSH 54 (2009), pp. I67-205 doi:I0.I0I7/So020859009000674

(C) 2009 Internationaal Instituut voor Sociale Geschiedenis

\title{
Striking Deaths: Lethal Contestation and the "Exceptional" Character of the American Labor Movement, I870-1970*
}

\author{
PAUL F. LIPOLD \\ Department of Sociology, University of Akron \\ E-mail: plipold@uakron.edu \\ L A R R Y W. Is A A C \\ Department of Sociology, Vanderbilt University \\ E-mail: larry.isaac@vanderbilt.edu
}

\begin{abstract}
Summary: The decades between the Great Railway Strike of I 877 and the post-WorldWar-II institutionalization of organized labor in the US have been impressionistically characterized by labor scholars as the most violent and bloody to be found in any Western, democratic nation. A variety of different forms of labor repression have been identified and studied. Yet because of a lack of systematic data, none have been able to examine directly the incidence and contours of the ultimate form of violent repression in collective contention. We create the conceptual space for pursuing bloodshed and a new data set featuring deaths resulting from labor strikes as a new and promising direction in the American exceptionalism debate and in studies of comparative strikes. Through a painstaking search of the historical record, we produce the first systematic quantitative gauge of striking deaths between 1870 and 1970. These data permit a mapping of fatalities resulting from labor strikes across time, geographical region, and industry. After describing configurations of strike-based mortality, we suggest what these patterned variations may mean and identify additional questions that these data may help resolve in subsequent studies. We urge comparable data collections in other countries that would permit direct comparative-historical assessments of the magnitude and role of bloodshed in different labor movements.
\end{abstract}

\footnotetext{
* This paper was presented at the European Social Science History Conference, 27 February 2008, University of Lisbon, Portugal. We thank Valerie Conner, Harry Dahms, John Myles, and Jill Quadagno for comments on earlier phases of this research, and Rick Rubinson, Vanderbilt University Library and Oberlin College Library (especially Julie Weir and Kemi Gbadebo) for data collection assistance. We are also grateful to Aad Blok, the IRSH editorial board, and anonymous reviewers for constructive suggestions that improved the paper. The second author gratefully acknowledges Vanderbilt University's College of Arts and Science for research support.
} 
A strike is a form of protest, characterized by the collective withdrawal of labor power producing a rupture in the wage relation - the economic exchange of labor power for a wage - so central to capitalist production and worker reproduction. As a form of collective contention, strikes are indicative of grievances held by a group of workers against one or more employers and they represent a temporary abeyance of the production process for the workplace target thereof. Strikes are, therefore, a form of contentious collective action that can be non-violent in all respects, or involve a wide variety of violence. Sometimes violent contention becomes fatal; blood is spilled and people killed in the course of the struggle. In the United States from I 877 through I947, there were no less than 270 strikes wherein at least one person was killed. The earliest recorded US strike occurred in 1775 when New York printers struck for higher wages, and won. ${ }^{\mathrm{I}}$ Yet by all indications the first strike to become lethal did not take place until i 850 , when two striking tailors were killed by police. ${ }^{2}$ However, between the I 870 s and the late I940s, a whole new "cultural epoch of contention" 3 was opened between capital and labor, one in which lethal industrial violence was relatively common. Both before I 877 and after the I940s, deaths resulting from labor strikes in America were, indeed, rare events.

One may or may not find intrinsic significance in the fact that more than I,०0० individuals were killed as a result of strike-related violence within the United States during these years. But what of the fact that American strikefatality rates were double that of France, ${ }^{4}$ and the fact that only one British striker was killed since I9II? Not only was the US apparently a more deadly arena for strikes than other Western nations, but within the US some industries and historical periods were more deadly than others. What of the fact that approximately 47.5 per cent of US strike fatalities occurred during disputes within the extractive sector (i.e. agriculture, mining, lumbering, fishing) while less than I.6 per cent of such deaths were recorded within all of the construction industries? How do we explain the concentration of strike deaths in the decades between I877 and I947?

We directly address these and related questions. But before such questions can be confronted, we need an empirical record of strike mortality about which we are confident, one that spans multiple industries, regions, and a

I. Fay M. Blake, The Strike in the American Novel (Metuchen, NJ, 1972), p. 4.

2. David Montgomery, Citizen Worker (New York, I993), p. 67.

3. Doug McAdam and William Sewell, Jr, "It's About Time: Temporality in the Study of Social Movements and Revolutions", in R. Aminzade, J. Goldstone, D. McAdam, E. Perry, W.H. Sewell, Jr, S. Tarrow, C. Tilly, Silence and Voice in the Study of Contentious Politics (New York, $200 \mathrm{I})$, p. II 2.

4. H.M. Gitelman, "Perspectives on American Violence", Business History Review, 47 (1973), pp. I-23.

5. Patricia Cayo Sexton, The War on Labor and the Left: Understanding America's Unique Conservatism (Boulder, CO, I99I). 
substantial swatch of history, one that is as systematic and comprehensive as possible. In this article we provide precisely that.

Massive and diverse literatures direct attention to these issues and offer limited empirical views along with fragmented theoretical accounts of the bloody path of the American labor movement. For example, the correlated topics of strike-related violence and fatalities have long attracted the attention of those seeking to maintain, transform, or understand the modern industrial system. Large-scale violent episodes such as the Great Railway Strike of 1877 and the Haymarket affair of I 886 alarmed industrialists and other elites in the late nineteenth century and aroused suspicions of incipient Marxist and anarchistic movements. The proliferation of industrial violence into the twentieth century inspired Progressive-Era journalists and reformers to seek ways to alleviate market and workplace conditions thought to inspire such strife, as did their successors during the New Deal. With the general cessation of strike-related violence during the post-World-War-II era, social scientists have increasingly looked to labor's turbulent past in an effort to explain its seemingly moribund present. ${ }^{6}$

Despite longstanding interest, the various research trajectories which comprise the literature are beset by seeming paradox and disconnect. For instance, a number of recent studies authored by historical sociologists have reinforced the view that government repression and policies have had an impact upon the strength and trajectory of the labor movement. ${ }^{7}$ Despite being identified as a determining factor in numerous strikes and movements, ${ }^{8}$ however, state and/or elite violence has achieved neither the requisite scrutiny nor been included in such models - the alluring implications of the perceived relationship between violence and "exceptionalism" left unknown. As a second example, most major theories of social movements have provided conceptual space for the role of repression, ${ }^{9}$ and sought to explain violence in terms of rational choice and tactical utility. ${ }^{10}$ Yet they have, by

6. Robert Goldstein, Political Repression in Modern America: From I870 to Present (Boston, MA, 1978); Daniel R. Fusfeld, "Government and the Suppression of Radical Labor, r 877-1918”, in Charles Bright and Susan Harding (eds), Statemaking and Social Movements (Ann Arbor, MI, 1984); Sexton, The War on Labor; Kim Voss, The Making of American Exceptionalism (Ithaca, NY, I993).

7. Larry Griffin, Michael Wallace, and Beth Rubin, "Capitalist Resistance to the Organization of Labor Before the New Deal: Why? How? Success?", American Sociological Review, 5I (1986), pp. I47-I67; Michael Goldfield, The Decline of Organized Labor in the United States (Chicago, IL, 1987); Michael Wallace, Beth Rubin, and Brian Smith, "American Labor Law: Its Impact on Working-Class Militancy, I90 I-I 980", Social Science History, I 2 (I988), pp. I-29.

8. Goldstein, Political Repression; Fusfeld, "Government and the Suppression".

9. Charles Tilly, From Mobilization to Revolution (Reading, MA, I978); Doug McAdam, Political Process and the Development of Black Insurgency, 1930-1970 (Chicago, IL, I982); Frances Fox Piven and Richard A. Cloward, Poor Peoples' Movements (New York, 1979). Io. William A. Gamson, The Strategy of Social Protest (Belmont, CA, 2nd edn, I990). 
and large, failed to explain the effects of violence upon movements beyond the facilitation of their unqualified success or failure. ${ }^{\text {II }}$ Finally, several thoughtful studies focusing on the causes of strike-related violence have nonetheless either failed to include the American case ${ }^{\mathrm{I} 2}$ and/or lacked sufficient methodological rigor. ${ }^{\mathrm{I}}$

Critical issues associated with the causes, consequences, and character of American labor-management violence have thus been left undertheorized. What caused the bloodshed on America's picket lines? How and why did picket line deaths in the United States vary across time, industry and region? Did the bloodshed have any substantive impact on the strength and trajectory of the American labor movement? How did bloodshed on American picket lines compare to the experiences of other nations? Was American bloodshed in some way "exceptional"? Through this paper and other incipient research, we hope to answer these questions while resurrecting a prior line of historical research with more systematic data that will allow new questions to be posed and answered. More than two decades ago, Charles Tilly neatly summarized the inherent relationship between violence and collective contention:

The occurrence of damage to persons or objects gives us some small assurance that at least one of the parties to the collective action took it seriously. More important, violence makes collective action visible: authorities, participants, and observers tend to set down some record of their actions, reactions, and observations. Collective violence therefore serves as a convenient tracer of major alterations in collective action as a whole $[\ldots]^{14}$

Consistent with our supposition that research into such issues has been hampered by the lack of comprehensive and reliable data, the formation of a new data set has been the centerpiece of our project to date. Through a painstaking search of the historical record, we have produced a new data set that is arguably the most comprehensive and reliable compilation of US strike-fatality data recorded to date, and includes: a descriptive list of almost 300 strikes and other violent labor events that resulted in more than I,200 strike fatalities for the years I 870-1970, broken down by historical period, region, industry, and in many cases, victim and aggressor status. In what follows, we: (I) frame our description of the data with the US exceptionalism debate; (2) describe the methodology employed in the collection of the strike mortality data; (3) map the basic topography of the strike fatalities

\footnotetext{
I I. Ibid.

I2. Edward Shorter and Charles Tilly, Strikes in France, 1930-1968 (Cambridge, I974); David Snyder and William R. Kelly, "Industrial Violence in Italy, I878-1903", American Journal of Sociology, 82 (1976), pp. I3 I-I62; Don Sherman Grant and Michael Wallace, "Why Do Strikes Turn Violent?”, American Journal of Sociology, 96 (I99I), pp. I I I7-I I 50.

I3. Taft and Ross, "American Labor Violence"; Goldstein, Political Repression.

I4. Tilly, From Mobilization, p. i 88.
} 
from the Gilded Age through the post-World-War-II decades; (4) suggest possible meanings of the reported configurations; and ( $s$ ) identify additional questions that might be addressed with these data in subsequent studies.

Far from the final word, therefore, this project represents a new beginning. Evidence presented in this paper is inadequate to adjudicate the exceptional character of American labor-management violence. The novelty of our approach rests not so much in a focus on violent repression, but in directly assessing the magnitude, location, and trajectory of extreme corporal violence visited upon the US labor movement. In this article we are primarily concerned with creating the conceptual space for, and empirical measure of, bloodshed in the US labor movement, and posing questions about what such bloodshed might mean in the context of the exceptionalism debate. We begin, then, by addressing the relative historical disconnect between theories of American exceptionalism and the role of violence therein.

\section{BRINGING BLOODSHED INTO THE EXCEPTIONALISM DEBATE}

Within the context of ascent as an international industrial power and workers struggling for voice in the workplace and often material existence outside, "American exceptionalism" was first assumed and then posed as a question. For much of the nineteenth century, a version of exceptionalism was held by many Americans, especially elites. This was the belief that class struggles between labor and capital or collective violence between rich and poor were conditions that plagued Europe but did not, and could not, because of exceptional circumstances, exist in the United States. The tumultuous uprising during the summer of 1877 , the inaugural national labor strike, was just the first in a series of events that shook the very foundations of that smug worldview. ${ }^{\text {Is }}$ But it was Werner Sombart's (1906) book that posed the question in stark terms - Why No Socialism in the United States? - and served as the lynchpin for what was to become the American exceptionalism debate over the next century. ${ }^{16}$

The vast literature which Sombart's book triggered would generate a host of different answers to that question, including the character and trajectory of the American labor movement. America's industrial take-off occurred within a context of unique structural and cultural conditions. As the argument goes, it was these conditions, that presumably shaped a

I 5. As one contemporary observer put it: the uprising of I 877 "seemed to threaten the chief strongholds of society and came like a thunderbolt out of a clear sky startling us rudely. For we had hugged the delusion that such uprisings belonged to Europe"; quoted in Jerry M. Cooper, The Army and Civil Disorder: Federal Military Intervention in Labor Disputes, 1877-1900 (Westport, CT, 1997), p. 44.

I6. Werner Sombart, Why Is There No Socialism in the United States? (White Plains, NY, [1906], 1976). 
relatively conservative working class, that led to a weak union movement and the absence of socialism in America.

Sombart answered his query - Why Is There No Socialism In The United States? - by identifying a series of structural conditions and workers' attitudes that made such a movement more difficult than in other countries like his native Germany. Socialism in America had been hampered by the lack of a feudal tradition, the prevailing two-party system, relatively high wages paid to American labor, and greater opportunities for geographical and social mobility. The emphasis of Sombart's assessment, then, was on the social, political, and economic structure of the nation and the relatively favorable attitudes of workers toward that system. Nowhere had he explicitly identified repression of the labor movement's agitation for change as an existing or even potential part of this puzzle.

Although he did not emphasize repression in his A Theory of the Labor Movement, Selig Perlman did recognize its existence. ${ }^{I 7}$ Given their experience with very bitter, protracted battles for rights, American workers' behavior seemed quite rational; experience with American politics, he argued, had taught them to be apolitical; and their experience with blackjacks had patterned their bargaining behavior. But far more important to Perlman was the excellent economic opportunities that workers experienced in America, endearing them to the system.

More recent studies have often advanced the role of key conditions prevailing at the moment of some major historical event that was a potential opportunity for the labor movement. Mike Davis pointed to a series of accumulated defeats for labor around key events, like the Civil War: "Labor's inability to become an independent political actor in the greatest national crisis in American history was due, in part, to the fact that the initial process of industrialization had tended to fragment rather than unify the working class." ${ }^{18}$ As Davis saw it, the key centrifugal forces behind this fragmentation were: (a) the urban-industrial frontier (rather than Turner's agrarian frontier) offering small entrepreneurial opportunities and geographical mobility that became surrogates for collective action; (b) nativism and cultural division within the working class as streams of immigrants entered the workforce; and (c ) racism. Alan Trachtenberg focused on the Gilded Age as the crucial period within which working and other classes became incorporated into a commercialized capitalist culture, thus undermining the movement of labor on a more radical trajectory. ${ }^{\text {I9 }}$

Some analysts equivocated on the issue of repression in shaping the trajectory of the American labor movement. Melvyn Dubofsky, for 
instance, was ambiguous and focused exclusively on the state when he wrote: "The history told in this book records as many instances of state intervention fostering collective action by working people as of cases in which the state repressed working-class militancy. At no time, however, did the state serve the interests of either capital or labor directly." ${ }^{20}$ Seymour Martin Lipset was less ambiguous on the role of repression, but did not see it as something especially peculiar to America. He conceded that syndicalist, socialist, and communist movements had suffered from political repression. However, he qualified his remarks in noting that, "anti-radical repression was much greater in many European countries, but did not prevent the emergence of large leftist parties". ${ }^{2}$ Other analysts have contradicted this point, noting that less repressive environments in nations like France and Great Britain helped to nurture their historically stronger labor traditions. ${ }^{22}$ Overall, Lipset's analysis of American exceptionalism accorded little significance to the role of repression. In the final analysis, he fell back upon the old consensus framework that had been established by Sombart and Perlman decades earlier.

Robert Goldstein was the first to argue that repression figured prominently in shaping both a relatively conservative character and trajectory for the US labor movement. He criticized the consensus school and pluralist models for overlooking the role of repression. In so doing, he argued that they obscured not only the true character of the American labor movement, but that of the state and its impact as well. He enumerated scores of events in American history whereby leftist labor and political organizations were repressed and speculated as to how the course of the labor movement might have been different had such violations of the constitution not occurred. ${ }^{23}$

Sanford Jacoby turned the exceptionalism question in a new direction by arguing that the distinctively weak US labor movement "cannot be understood without taking into account national differences in management characteristics and policies". According to this view, it was the American employers who were exceptional in their economic incentives, values, and political structure. Consequently, the exceptional weakness of the US labor movement was seen as a product of the strength and

20. Melvyn Dubofsky, The State and Labor in Modern America (Chapel Hill, NC, 1995), p. 236.

2 I. Seymour Martin Lipset, American Exceptionalism (New York, 1996), p. 86.

22. For example, see Gerald Friedman, "The State and the Making of the Working Class: France and the US, I880-1914", Theory and Society, I7 (1988), pp. 403-430; Victoria C. Hattam, "Institutions and Political Change: Working-Class Formation in England and the United States, I 820-1896”, Politics and Society, 20 (1992), pp. I33-166.

23. Goldstein, Political Repression. 
hostility of employers who deprived the working class of effective organization. ${ }^{24}$

Others would follow the leads of Goldstein and Jacoby, but often in quite different ways. ${ }^{25} \mathrm{Kim}$ Voss redefined the exceptionalism debate in an important manner. ${ }^{26}$ She argued that prior to the late $\mathrm{r} 88 \mathrm{os}$, American workers were in their consciousness, organization, and actions, very much like their British and French counterparts. The American labor movement was launched on its exceptional route with the collapse of the Knights of Labor (KOL) in I 886-I 887. So to the key: how did the KOL collapse set US labor on a different path? In addition to a variety of other conditions that weakened the KOL, this inclusivist labor organization was destroyed in the class struggle largely by a more powerful counter-movement of employers' associations. These associations attacked the KOL as local, state, and federal officials looked on from the sidelines, and the class war was lost in the last decade of the nineteenth century. In the end, what was really exceptional about US labor politics, according to Voss, was not labor but capital and the state at this crucial historical juncture.

Jeff Haydu's recent study of business communities and labor in the late nineteenth and early twentieth centuries concurs, in part, with Voss on the significance of the American business alliance with government against the labor movement. However, his argument finds the major turning point a bit later in history than does Voss. For Haydu, labor-management relations were set on an exceptional trajectory early in the twentieh century when the National Association of Manufacturers launched their "open-shop" counter-offensive against the union movement. ${ }^{27}$

Since Goldstein, then, it is possible to identify a loosely confederated adverserialist or class struggle/repression approach to the exceptionalist question consisting of the following basic presuppositions. (I) Capitalist fears of working-class militancy and radicalism became greatly aroused during the latter quarter of the nineteenth century, especially after i $877 .^{28}$

\footnotetext{
24. Sanford M. Jacoby, "American Exceptionalism Revisited: The Importance of Management", in idem (ed.), Masters to Managers: Historical and Comparative Perspectives on American Employers (New York, 1991), p. 565.

25. For example, see Friedman, "The State and the Making of the Working Class"; Fusfeld, "Government and the Suppression"; Sexton, The War on Labor.

26. Voss, The Making of American Exceptionalism, ch. 8.

27. Jeffrey Haydu, Citizen Employer (Ithaca, NY, 2008), p. 4.

28. Friedman, "The State and the Making of the Working Class"; Sean Wilentz, "Against Exceptionalism: Class Consciousness and the American Labor Movement, I790-1920", International Labor and Working-Class History, 26 (1984), pp. I-24; David Montgomery, "Strikes in Nineteenth Century America", Social Science History, 4 (I980), pp. 8I-I04; idem, Citizen Worker; Larry Isaac, "To Counter 'The Very Devil' and More: The Making of Independent Capitalist Militia in the Gilded Age", American Journal of Sociology, 108 (2002), pp. 353-405.
} 
(2) Capitalist resistance coalesced within both public and private sectors in the form of anti-labor legislation and court rulings, ${ }^{29}$ employer associations ${ }^{30}$ militias, ${ }^{31}$ the army, ${ }^{32}$ armed coalitions between employers and local officials, ${ }^{33}$ hired mercenary strike-breakers and union busters, ${ }^{34}$ and episodes of often brutal physical repression resulting in bloodshed. ${ }^{35}$ (3) Repressive counter-response was not uniform, but rather varied across time, ${ }^{36}$ across industry, ${ }^{37}$ falling disproportionately on leftist labor organizations. ${ }^{38}$ (4) Differential repression prior to World War I served to isolate and discourage leftist labor organizations relative to more conservative counterparts, thereby encouraging a more conservative American labor movement. ${ }^{39}$ (5) Given evidence that the early American labor movement was not particularly conservative, ${ }^{40}$ arguments for the exceptionalism of class relations in

29. Christopher Tomlins, The State and the Unions (Cambridge, 1985); Holly McCammon, "'Government by Injunction': The US Judiciary and Strike Action in the Late igth and Early 20th Centuries", Work and Occupations, 20 (1993), pp. 174-204.

30. Griffin et al., "Capitalist Resistance"; Voss, The Making of American Exceptionalism; Haydu, Citizen Employer; Patrick McGuire, "Instrumental Class Power and the Origin of Class-Based Regulation in the US Electric Utility Industry", Critical Sociology, I6 (I989), pp. I $8 \mathrm{I}-203$.

31. Jerry M. Cooper, The Rise of the National Guard (Lincoln, NE, I997); Isaac, "To Counter 'The Very Devil'”.

32. Cooper, The Army and Civil Disorder.

33. Larry Isaac, "Policing Capital: Armed Countermovement Coalitions Against Labor in Late I 9 th-Century Industrial Cities", forthcoming in Nella Van Dyke and Holly McCammon, Strategic Alliances: New Studies in Social Movement Coalitions (Minneapolis, MN, forthcoming, 2010).

34. Warren C. Whatley, "African-American Strikebreaking from the Civil War to the New Deal”, Social Science History, I 2 (1993), pp. I-29; Stephen H. Norwood, Strike-Breaking and Intimidation (Chapel Hill, NC, 2002); Robert Michael Smith, From Blackjacks to Briefcases (Athens, $\mathrm{OH}, 2003$ ); Larry Isaac and Daniel Harrison, "Corporate Warriors: The State and Changing Forms of Private Armed Force in America", Current Perspectives in Social Theory, 24 (2006), pp. I53-188.

35. Taft and Ross, "American Labor Violence".

36. Dubofsky, The State and Labor.

37. Jeffrey Haydu, "Employers, Unions, and American Exceptionalism: A Comparative View", International Review of Social History, 33 (1988), pp. 25-4I.

38. Friedman, "The State and the Making of the Working Class"; Fusfeld, "Government and the Suppression of Radical Labor".

39. Ibid.; Hattam, "Institutions and Political Change"; Bruce C. Johnson, "Taking Care of Labor: The Police in American Politics", Theory and Society, 3 (1976), pp. 89-1 I7; Herbert Hovenkamp, "Labor Conspiracies in American Law, 1880-1930", Texas Law Review, 66 (1988), pp. 919-965; Tomlins, The State and the Unions; Voss, The Making of American Exceptionalism.

40. For arguments and evidence against a conservative working-class in the early US labor movement, see Voss, The Making of American Exceptionalism, and Neville Kirk, "Peculiarities versus 'Exceptionalism': The Shaping of the American Federation of Labor's Politics during the I 890 s and I900s", International Review of Social History, 45 (2000), pp. $25-50$ on the Knights of Labor; Kimmeldorf, Battling for American Labor, and Kirk "Peculiarities versus 'Exceptionalism'” 
the US might best be found in a climate of intimidation created by an exceptional capitalist counter-movement and a complicit state that stifled labor organization of any kind, not just radical factions. It is in this sense that mortality produced in the context of workers' struggles over voice in the workplace is so important.

Clearly, there remains ambiguity among scholars as to the validity of the American exceptionalism claim. Neville Kirk ${ }^{4 \mathrm{I}}$ for instance, has argued that even the much maligned American Federation of Labor was not exceptionally different from its British counterpart, the Victorian British Trades Union Congress, at least through the I890s and into the I900s. Given the similarities between the American and British cases, we are left to assume, perhaps it was not the American labor movement that was exceptional, but rather Sombart's native Germany. ${ }^{42}$ Some recent scholarship has called into question the notion of American employers' exceptionalism, ${ }^{43}$ while others have suggested that American exceptionalism is best understood from a regional - especially Southern ${ }^{44}$ - perspective rather than from the national point of view. While some may be prepared to abandon the entire enterprise, we find that scholarship which has sought to demonstrate the impact of various facets of elite repression upon the strength and trajectory of the American labor movement to have been too compelling to ignore, especially insofar as the most direct and forceful form of repression - lethal violence - has heretofore not received the analytical attention it deserves.

Repression is a complex, multidimensional concept. ${ }^{45}$ While some studies have creatively produced empirical measures of key dimensions of capitalist resistance and repression, ${ }^{46}$ no study has been able to gauge directly the extent and role of bloodshed and death faced by workers as the ultimate form of repression of labor movements in the US and elsewhere. To a large extent, a major problem has been the episodic and therefore fragmentary character of data on strike deaths in the literature.

on the AFL; and Melvyn Dubofsky, We Shall Be All: A History of the Industrial Workers of the World, 2nd edn (Chicago, IL, I988) on the IWW; Larry Isaac, "In Search of American Labor's Syndicalist Heritage", Labor Studies Journal, 27 (Summer 2002), pp. 2 I-37 for an extension of Kimeldorf on the AFL and IWW.

4I. Kirk, "Peculiarities versus 'Exceptionalism"”.

42. For instance, see Marcus Kreuzer, "Parliamentarianization and the Question of German Exceptionalism: I867-1918", Central European History, 36 (2003), pp. 327-357.

43. Andrew Yarmie, "Employers and Exceptionalism: A Cross Border Comparison of Washington State and British Columbia, I890-1935", Pacific Historical Review, 72 (2003), pp. 56I-6I5.

44. Friedman, "The Political Economy of Early Southern Unionism".

45. Jules Boykoff, "Limiting Dissent: The Mechanisms of State Repression in the USA", Social Movement Studies, 6 (2007), pp. 28 I-310.

46. Griffin et al., "Capitalist Resistance"; Whatley, "African-American Strikebreaking"; McCammon, "Government by Injunction”. 


\section{A FRAGMENTARY VIEW OF LETHAL CONTESTATION AND THE AMERICAN LABOR MOVEMENT}

What scholars believe they know about the lethal character of strikes in the US is based on very fragmentary evidence. This image emerges from a variety of different and scattered historical case studies focusing on the late nineteenth and twentieth centuries. Additionally, there have been a few attempts to compile strike-mortality data that span multiple events. A sense of such events and studies about lethal strikes is helpful for understanding the scholarly literature and for gaining an appreciation of the fragmentary character of knowledge about lethal strikes.

The details of each life lost, so far as they are known, vary. Victims were claimed during both interclass and intraclass struggles, as otherwise peaceful strikes escalated into bloody conflicts that pitted strikers against company guards, police, militia, and even federal troops on the one hand, and non-strikers, replacement workers, or even rival union members on the other. On a July morning in Martinsburg, West Virginia, for instance, William P. Vandegriffe, a striking rail worker, took aim and fired upon a militiaman who had been commissioned to assist the Baltimore and Ohio Railroad to move their trains out of the station in the face of striker resistance. Fellow militiamen returned fire, mortally wounding Vandegriffe, who died nine days later - thus consummating the first fatal incident in what came to be known as the Great Railway Strike of $1877 .{ }^{47} \mathrm{We}$ know that Vandegriff shot first, and that his death, therefore, may have arguably been attributable to his own aggression. But the situation was somewhat different in the coal mining regions of Ludlow, Colorado during the spring of I9I4. On 20 April of that year, a militia force moved to evict a group of striking miners from a tent colony that they had established for themselves and their families after having been evicted from company housing held by the mine owners. Without provocation, the militia opened fire upon the strikers with rifles and machine guns, killing five men and a boy. They next attacked the tents where an additional eleven children and two women perished, engulfed in flames. ${ }^{48}$

In I9I9, a confrontation during an attempt to organize sharecroppers near the town of Elaine, Arkansas, resulted in the death of the local sheriff. During the racially motivated rampage that followed, five vigilantes were killed as were at least 200 African-American farm laborers. ${ }^{49}$ The opposite dynamic came into play three years later in the coal mining regions near the small town of Herrin, Illinois. In that instance, the

47. Robert Bruce, I877: Year of Violence (Chicago, IL, I959), pp. 77-78.

48. Taft and Ross, "American Labor Violence", p. 33 r.

49. Nan Elizabeth Woodruff, American Congo: The African American Freedom Struggle in the Delta (Cambridge, MA, 2003). 
Southern Illinois Coal Company broke with the local union that had existed for more than twenty years, thereby prompting a strike by union miners. ${ }^{\circ}$ On 2 I June I922, company guards killed three strikers as they protested the employment of non-union strike-breakers. During the predawn hours of the following day, the strikers retaliated by massacring a total of nineteen individuals, including strike-breakers, guards, and company officials over the course of a vengeful forced march.

On numerous other occasions, strikes assumed the form of pitched battles. In I 892, displaced union workers squared off against a deployment of Pinkerton guards outside Andrew Carnegie's famed steel mill in Homestead, Pennsylvania. ${ }^{51}$ In I9I 5 , strikers and company guards took aim at one another in and around fixed barricades at the Standard Oil refinery in Bayonne, New Jersey. ${ }^{52}$ And a full-scale gun battle was waged in $192 \mathrm{I}$, between striking miners and deputy sheriffs on Blair Mountain in Logan County, West Virginia, before 2, I00 federal troops arrived to stop the war. ${ }^{53}$

The casualty figures mounted quickly. More than roo lives were lost during the Great Railway Strike of I 877. Seventy-four perished during the Colorado mine war that included the Ludlow Massacre. More than 200 died in Elaine. Twenty-two were killed in Herrin, eleven in Homestead, two different strikes at Bayonne claimed a combined total of at least eight lives, and an estimated twenty-one persons were killed on Blair Mountain. In addition, violence during a I920 coal strike in Matewan, West Virginia took the lives of seven Baldwin-Felts agents, two strikers, and the town's mayor. Thirteen were killed in McKees Rock, Pennsylvania during a strike against the Pressed Steel Car Company in 1909, eleven of whom were strikers. Thirteen persons were killed in 1904, all of whom were strike-breakers, by a dynamite blast while awaiting a train in Cripple Creek, Colorado; and yet another twelve were killed during a pitched battle in Mucklow, West Virginia on 26 July i9i 2, most of them guards. National strikes such as the Pullman Railway Strike of I894, the National Shopmen's Strike of 1922, the General Textile Strike of 1934, and the Little Steel Strike of 1937 resulted in totals of thirty-four, twenty-two, fifteen, and sixteen fatalities, respectively. Altogether, more than I,000 strike-related fatalities were recorded during at least 270 separate strikes,

50. Paul M. Angle, Resort to Violence (London, 1954).

5. Paul Krause, The Battle of Homestead (Pittsburgh, PA, I992); David P. Demarest, Jr (ed.), The River Ran Red: Homestead, I892 (Pittsburgh, PA, I992).

52. John A. DeBrizzi, "The Standard Oil Strikes in Bayonne, NJ, I9i 5-16", New Jersey History, Iо ( (1983), pp. I-I I; Morris Schonbach, Radicals and Visionaries: A History of Dissent in New Jersey (Princeton, NJ, 1964).

53. Price V. Fishback, "An Alternative View of Violence in Labor Disputes in the Early r 900 :

The Bituminous Coal Industry, I890-1930”, Labor History, 36 (1995), pp. 426-456. 
across a dozen industries on American soil during a seven-decade span from 1877 to 1947. These are the grounds on which historians have identified the American labor movement as the most contentious ${ }^{54}$ and bloodyss of any Western industrialized nation.

Labor historians have long sought to record and account for violent episodes in the context of the American labor movement. Yet historical sociologists have generally ignored these topics, quite likely because of the difficulties associated with compiling systematic data. But such neglect is incongruent with both existing sociological theory and at least three areas of sociological research. First, a number of studies authored by historical sociologists have reinforced the view that government repression and policies have had an impact upon the strength and trajectory of the US labor movement. ${ }^{56}$ Despite being identified as a determining factor in numerous strikes and movements, ${ }^{57}$ however, state and/or elite violence has achieved neither the requisite scrutiny nor been included in such models. Second, most major theories of social movements have provided conceptual space for the role of repression, ${ }^{58}$ yet we do not know what role lethal violence played in shaping the labor movement. Finally, several thoughtful studies focusing on the causes of strike-related violence have, nonetheless, either failed to include the US case ${ }^{59}$ and/or lacked sufficient methodological rigor. ${ }^{60}$

As a result, lethal violence involved in the formative era of labormanagement relations, from the American Civil War to World War II, has been dramatically under-theorized, largely because it has been dramatically under-mapped empirically. The existence of violence may indicate the seriousness of collective contention, as Tilly has argued, ${ }^{6 \mathrm{I}}$ but it also signals high-risk activism, especially when there is a well-established legacy of violence over a particular type of collective contention. The lives of workers were waged upon either joining or ignoring a strike; and their deaths stand as both a manifestation of and testament to the determination of all parties involved to assert and/or protect their perceived rights to property and labor. These assertions and the seriousness with which they

54. Ronald Filipelli (ed.), Labor Conflict in the United States: An Encyclopedia (New York, 1990).

55. Taft and Ross, "American Labor Violence".

56. Griffin et al., "Capitalist Resistance"; Goldfield, The Decline of Organized Labor; Wallace et al., "American Labor Law".

57. Goldstein, Political Repression; Fusfeld, "Government and the Suppression".

58. Tilly, From Mobilization; McAdam, Political Process; Piven and Cloward, Poor Peoples' Movements.

59. Shorter and Tilly, Strikes in France; Snyder and Kelly, "Industrial Violence in Italy"; Grant and Wallace, "Why Do Strikes Turn Violent?".

60. Taft and Ross, "American Labor Violence"; Goldstein, Political Repression.

6r. Tilly, From Mobilization, p. I88. 
were made during specific events likely affected the tone and course of subsequent events. Until the violence and bloodshed are accounted for within our socio-historical analyses, however, we simply cannot know.

The neglect of strike-related violence and deaths by sociologists has been at least in part attributable to the lack of comprehensive data. The federal government has provided no record of strike-related injuries and deaths, ${ }^{62}$ and the body counts provided by historians have constituted either broad non-comprehensive surveys of industrial violence without particular regard to fatalities; ${ }^{63}$ or focused upon narrowly defined time periods, ${ }^{64}$ industries, ${ }^{65}$ and events ${ }^{66}$ and therefore are fragmentary at best.

Philip Taft and Philip Ross ${ }^{67}$ as well as Robert Justin Goldstein ${ }^{68}$ provide the two most comprehensive works on violence within and against the labor movement, respectively. The Taft and Ross study is the most inclusive, providing a general survey of violent strikes and related events across industries from the I 870 s through the early post-WorldWar-II era. Goldstein's study of political repression provides a similar anthological style and scope of coverage across time and industry. However, his focus upon instances of elite violence and the plight of radical segments within the labor movement fail to capture the intraclass nature of many of the struggles between strikers and non-strikers, union and non-union employees, and even members of rival unions reported by Taft and Ross. References to picket-line shootings, beatings, and stabbings colorfully embellish both historical narratives as they outline the general terrain of US strike violence. As general surveys of violence and repression, however, neither Taft and Ross nor Goldstein intended to provide complete accounts of strike-related fatalities and injuries. Despite documenting more than 700 strike-related deaths and several thousands of injuries, their counts self-admittedly "grossly understate[d] the casualties" " ${ }^{69}$ Similar conclusions could be drawn regarding Ronald Filipelli's ${ }^{70}$ encyclopedic account of 254 of the most "pivotal" conflicts in American labor history. The individual entries provided therein offer insight into the causes of these particular strikes and often richly describe the events and

\footnotetext{
62. Sexton, The War on Labor.

63. Taft and Ross, "American Labor Violence"; Goldstein, Political Repression.

64. John Steuben, Strike Strategy (New York, I950); Rhodri Jeffreys-Jones, "Violence in

American History: Plug-Uglies in the Progressive Era", Perspectives in American History,

8 (1974), pp. $465-583$.

65. Fishback, "An Alternative View".

66. Philip Foner, The Great Labor Uprising of I 877 (New York, I977); Donald McMurry, The

Great Burlington Strike of I 888 (Cambridge, MA, 1956).

67. Taft and Ross, "American Labor Violence".

68. Goldstein, Political Repression.

69. Taft and Ross, “American Labor Violence”, p. 380.

70. Filipelli, Labor Conflict.
} 
circumstances that precipitated their resolution. Although reports of deaths and injuries are occasionally included in these synopses, no apparent concerted effort was made to include all such incidents. Filipelli's emphasis on large strikes, moreover, no doubt systematically excluded fatalities known to have occurred in smaller, lower-profile events.

Fortunately, several more narrowly focused analyses can be used to supplement these broader studies. Though more modest in terms of temporal and spatial scope, they were more clearly focused on strike casualties. Rhodri Jeffreys-Jones's ${ }^{71}$ study of strike-related violence during the Gilded Age and Progressive Era, for instance, identified 308 fatalities from I 890 through I909. Without specifying whether the deaths were to strikers, strike-breakers, guards, or some other category of victims, Jeffreys-Jones did offer an inter-industry comparison of total mortality figures by location and year. The Labor Research Association $(\mathrm{LRA})^{72}$ provided yet another source regarding strike fatalities by reporting the location and circumstances of more than I30 deaths of workers and labor organizers who were killed during strikes and organizing-related functions between the years I934 and I949. As reproduced in Steuben, ${ }^{73}$ the LRA data were detailed enough to specify the date, location, and name of each worker killed. Yet, their exclusive focus on working-class deaths during interclass struggles understated the overall level of strike-related mortality much as Goldstein's ${ }^{74}$ work did.

Still others have provided needed insight into specific industries and events. Price V. Fishback, ${ }^{75}$ for instance, gave a brief synopsis of more than sixty violent strikes and concomitant deaths within the bituminous coal industry between the years I877 and 1927. His list was compiled through a survey of secondary sources that included both Taft and Ross ${ }^{76}$ and Jeffreys-Jones. ${ }^{77}$ Robert V. Bruce's ${ }^{78}$ case history of the Great Railway Strike of 1877 , specifically accounted for the names and circumstances of seventy-eight persons killed during that multi-episode event for which the above sources failed to provide a total mortality figure. And as a final example that illustrates the value of case studies, Donald L. McMurry $^{79}$ recorded the deaths of four individuals during a strike against

71. Jeffreys-Jones, "Violence in American History".

72. Labor Research Association, Labor Fact Book III (New York, I936); Labor Fact Book IV

(New York, 1938).

73. Steuben, Strike Strategy.

74. Goldstein, Political Repression.

75. Fishback, "An Alternative View".

76. Taft and Ross, "American Labor Violence".

77. Jeffreys-Jones, "Violence in American History".

78. Bruce, I877: Year of Violence.

79. McMurry, The Great Burlington Strike. 
the Chicago, Burlington \& Quincy Railroad Company in I888, an event that had been overlooked by each of the aforementioned studies.

Collectively, these works portray US labor relations during the period I 877-I947 as violent, perhaps even exceptionally so; and encourage theoretical speculation about the variation in strike deaths across time, region, industry, and nation. As individual sources of strike-fatality data, however, they lack the systematic scope and reliability required for either sound theoretical development and/or statistical inference and modeling. This is the void we seek to fill, thereby opening the topic of American labor-management bloodshed to a more rigorous historical-sociological analysis. We begin with the data collection strategy. ${ }^{80}$

\section{METHODS FOR STRIKE FATALITY DATA COLLECTION}

Because this systematic collection of strike fatality data is the first of its kind, and because we hope to encourage similar projects on strike deaths in other countries, the details of our data-collection strategy are especially important. As described below, the specific strategies deployed in constructing this data set were systematic but otherwise not particularly novel - consisting of manual and computer-assisted searches of library holdings, books, and journals; content analysis; and cross-references.

Our data-collection strategy draws upon three major types of sources historical compilations, historical case studies, and newspapers - all subject to error. Given the basic information we are collecting, underreporting, especially systematic under-reporting (selectivity bias) was our biggest concern. Underestimation may have resulted from the failure to account for all fatalities produced by a particular event, or the failure to account for all events. Deaths and murders, too, may have gone undetected or been obscured by complicit authorities, ${ }^{8 \mathrm{I}}$ a common phenomenon in the South under the Jim Crow regime of American apartheid. Even more likely, strike fatalities in obscure regions or events may have gone unnoticed in a given record, or they may have occurred from the lingering effects of strike-related injuries long after the official mortality counts had been made. One might even suspect that the likelihood of accounting errors increases backward through time, thereby introducing systematic bias into strike-fatality counts - although neither we nor other scholars have provided evidence of such a trend.

80. The data collection strategy of aggregating limited systematic data compilations with multiple case studies containing strike deaths was established in Paul F. Lipold, "Laying it All on the Line: The Configuration \& Causes of Strike Fatalities within the United States, I 877-I 947" (unpublished Ph.D. dissertation, Department of Sociology, Florida State University, Tallahassee, FL, 2003). The present study augments that data collection strategy with major newspaper searches as well.

81. Steuben, Strike Strategy. 
Secondary sources, of course, can compound primary errors. Strikes are often complex, comprising multiple violent episodes and encompassing multiple locations and/or industries. The Great Railway Strike of I 877 and the Pullman strike in 1894 were two such events, assuming both a national character, and engendering sympathy strikes from coal miners and workers in other industries. Events can thus be conflated, thereby jumbling fatality counts; and partial/incomplete records may be mistaken for the whole, thereby diminishing accuracy. Even more likely, the varied goals and scopes of individual studies may be designed such that particular deaths may be ignored altogether. Recall that the Labor Research Council ${ }^{82}$ was interested in the deaths of only strikers.

One might thus idealize primary records. But there is no reason to believe that local archives could provide sufficient information on a large proportion of violent strikes, even if such a strategy were economically feasible. Secondary sources do have their advantages. First, they are more accessible than isolated archival material. Second, they are more conducive to portraying the forest through the trees. That is to say, they provide general overviews of strike violence and mappings of strike deaths that might not otherwise be attained through the primary records of often local and isolated events.

Given an unknown population of events (deaths resulting from strikes) and limited resources, the objective was to devise a compilation strategy that most advantageously balanced the informational veracity of the major sources of US strike-fatality data ${ }^{83}$ on the one hand, against their suspected omissions, biases, and errors on the other. To that end, data were compiled through a cross-reference/content analysis of the six major secondary sources of US strike-fatality data and several dozen supplementary works. First, we sought to identify those strikes known to have involved fatalities. Second, we sought to identify the total number of fatalities reported for each such event, thereby ensuring the most accurate total count possible.

We also supplemented our use of historical case studies and historical survey compilations with newspaper sources. Specifically, we did an online search of five major national newspapers - the New York Times (I870-1970), Chicago Daily Tribune (1872-1970), Washington Post (1877-1970), Atlanta Constitution (I868-1939), and Los Angeles Times (I88I-1970) - using the search terms "striker(s) killed". Interestingly, press coverage of strike deaths reported in these major US papers constituted only a small fraction of such fatalities aggregated through other historical sources described above, providing an additional (non-redundant) sixty deaths, 5.4 per cent of the overall record. To appreciate the reliability of the annual summary counts below,

82. Ibid.

83. Taft and Ross, "American Labor Violence"; Goldstein, Political Repression; Jeffreys-Jones, "Violence in American History"; Steuben, Strike Strategy; Fishback, "An Alternative”; Filipelli, Labor Conflict. 
we give an overview of the collection and compilation process, the numerous error minimization strategies, safeguards, and specifications embedded therein.

\section{Event specification}

Commensurate to the goal of gaining insight into the causes and consequences of violence both within and against the American labor movement, the search was neither victim- nor industry-specific, encompassing instead all strike-related deaths incurred within the United States from I 870 through 1970. Strike fatalities were defined as deaths to any individuals that directly resulted from violence for the purposes of either conducting, advancing, resisting, or inhibiting a strike/voluntary workstoppage and/or lock-out. Any death, therefore, has been included, so long as it both occurred during the course of a strike and could be reasonably attributed to some contested form of strike activity. It is important to note that our definition of strike deaths also excludes deaths visited upon labor movement actions that were not engaged in strike activity. For instance, such non-strike actions would include lethal attacks on members of the Industrial Workers of the World (IWW) ${ }^{84}$ or black sharecroppers attempting to organize in Elaine, Arkansas. ${ }^{85}$

\section{Periodization}

The temporal parameters were derived from US labor historiography. The time-frame bracketed by the beginning of the Gilded Age (I870) and passage of the Taft-Hartley Act of 1947 marked a historically unique period of US labor relations. Unprecedented in scale and violence, the Great Railway Strike in 1877 both frightened and puzzled American industrialists; and invoked a seven-decade struggle during which the prevailing structure of labor relations was both in flux and hotly contested by labor, capital, and state. More than any other era in American history and possibly the histories of other Western industrialized nations, labor conflicts within the US frequently resulted in open conflict, bloodshed, and lives lost. This era of violence came to a close by the end of the I940s. Certainly, not all of the fatalities common to American strikes occurred within the period I 877 to I947. Strike deaths have been recorded as early as $1850,{ }^{86}$ and we have uncovered thirty-one strike fatalities in the years

84. Dubofsky, We Shall Be All.

85. Woodruff, American Congo.

86. Montgomery, Citizen Worker, p. 67 indicates that the "first American workers ever to be killed in an urban strike" were two German tailors killed by police during the i 850 tailors' strike. Moreover, the number of strike deaths between I850 and I877 was apparently low compared to what was to come during the Gilded Age and subsequent decades. 
between 1947 and $1970 .{ }^{87}$ Nevertheless, the vast corpus of violence both within and against the labor movement occurred in the time frame bracketed by the Great Strike of I 877 and the years immediately following World War II.

\section{Data collection/content analysis}

Among most studies of US strikes and strike violence, strike-fatality references were typically embedded within the historical narratives. Only two major sources, Jeffreys-Jones ${ }^{88}$ and Steuben, ${ }^{89}$ provided lists from which the relevant fatality data could be obtained directly. Otherwise, content-analysis strategies needed to be devised whereby fatality references could be extracted from the historical texts. All too infrequently, references to "strike violence", "strike casualties", or similar keywords might have been indexed towards the back of a given work. For the most part, however, the content-analysis strategy simply entailed the direct reading of entire narratives for the necessary key/trigger words. These included but were not limited to nominative terms such as "fatalities", "deaths", "lives lost", and/or active references such as "killed", "murdered", or "mortally wounded". Injuries were never assumed to have been fatal without supporting evidence. For instance, upon reading that a striker had been "shot", neither "shot to death" nor "shot and killed" were assumed without the requisite qualifying information and/or remarks such as "and died later". "Casualties" could refer to either deaths or injuries: deaths, in such instances, were also not assumed.

\section{Organization}

Once a strike involving fatalities was identified, a record of the total fatality count, year, location, and industry of each event was transcribed into a database. Where available, other pertinent but non-essential information regarding the nature of the strike violence, and/or victims was also ascertained. The list of strikes and similar violent episodes that resulted in at least one fatality within the United States between the years I $877-$ I 947 contains 282 events, or individual entries. These include 270 strikes, 6 attacks against organizers/organizing drives not directly involving strikes, 3 internecine jurisdictional disputes also not directly involving strikes, and 3 attacks against pro-employment rallies. Our file contains a brief description of each event, total number of fatalities recorded for each event, along with relevant citations.

87. A portion of these postwar deaths are from our press sources and some are from Taft and Ross, "American Labor Violence".

88. Jeffreys-Jones, "Violence in American History".

89. Steuben, Strike Strategy. 


\section{Cross-reference/supplementation}

In providing the "best estimate" of fatalities for each event, we openly acknowledge the sustained probability of error. As described above, the foundational sources of our compilation were fashioned according to the varied goals and scope of each project - overlapping in certain events and perhaps altogether obscuring others. No single work sought to account for all of the strike-related fatalities during the period in question while some strikes involving fatalities were included within multiple studies. Their combined fatality count was thus bound to be marred by inconsistencies and missing data. Numerous case studies and other supplementary works were thus employed to corroborate evidence, reveal oversights, and otherwise mediate disputes. Supplementary works were pursued through citations within known sources, snowball accumulation of additional sources, and computer-assisted searches of library catalogues utilizing the key terms "strikes" and "violence".

\section{Count mediation/revision}

Sometimes multiple sources yield conflicting information. In such cases, we worked to mediate and produce the best estimate of deaths. The Battle of Homestead provides a case in point. The Homestead strike of I 892, for instance, involved a storied clash between striking workers at Andrew Carnegie's famed steel mill along the banks of the Monongahela River and a contingent of Pinkerton Guards who were called upon to police the picketers. The Pinkertons arrived on site in a floating river barge; but their landing was bitterly opposed by the armed picketers whom they had been summoned to police. Consensus holds the resulting battle as one of the most dramatic in American labor history. Casualty reports, however, were quite disparate. Taft and Ross ${ }^{90}$ claimed the deaths of two Pinkertons and two strikers. Jeffreys-Jones ${ }^{9 \mathrm{I}}$ reported a total of ten deaths; and Goldstein ${ }^{92}$ claimed fatalities of nine strikers and seven Pinkertons.

Initial research only muddled the count. Wolff, ${ }^{93}$ cited by Goldstein, claimed the deaths of "approximately" nine strikers and seven Pinkertons. Fortunately, the prominence of the strike had enticed much study. Even the detailed case histories, however, lacked consensus. Burgoyne, ${ }^{94}$ for instance, provided a coroner's list that included seventeen names of individuals whom were listed as either "dead" or "fatally wounded", seemingly suggesting that seventeen individuals had indeed died. Only

90. Taft and Ross, “American Labor Violence”, p. 295.

91. Jeffreys-Jones, "Violence in American History", p. 582.

92. Goldstein, Political Repression, p. 46.

93. Leon Wolff, Lockout: The Story of the Homestead Strike of I 892 (New York, 1965).

94. Arthur G. Burgoyne, The Homestead Strike of I 892 (Pittsburgh, PA, I979). 
three of these were identified as Pinkertons. A study of the Pinkertons by James D. Horan and Howard Swiggert ${ }^{95}$ confirmed that only three Pinkertons were killed during the event, as did two centennial case histories of the Homestead strike. ${ }^{96}$ These latter studies also served to refine the casualty count among the workers, the most convincing argument of which was made by Krause, ${ }^{97}$ who claimed that only the deaths of six workers and two sympathizers could ultimately be confirmed. We have thus accepted the deaths of three Pinkertons, six strikers, and two sympathizers as historically factual, and recorded the total fatality count for the event as eleven.

We have not been able to reconcile all such known discrepancies. Due to the imperfections inherent to the historical record, some incidents simply lack a sufficient documentation of any sort. Historians have suggested that official mortality figures likely underestimated the true number of fatalities in such events as the Great Railway Strike of $1877^{98}$ and the coalfield wars of Appalachia, ${ }^{99}$ for instance, because family members or friends often removed and buried corpses without formal inquiry. Where discrepancies remained, the total fatality count listed per event represents the most conservative estimate barring strong evidence to the contrary. Although conservative estimates are not necessarily the most accurate, such an approach serves to minimize the risk of overstating case mortality.

Estimates for an indeterminate number of events thus remained potentially incomplete. Other relevant events were likely missing altogether. However, given the efforts and safeguards that went into the data collection, we are confident that the compilation reasonably approximates the general contours of US strike fatalities as found within the historical record - the full reality of which will forever remain unknown.

\section{Nerwspaper data biases}

We have endeavored to uncover all strike deaths from historical compilations and historical case studies. In addition to our attempts to minimize under-reporting error associated with these sources discussed above, we have supplemented our data with searches of five major newspapers. The fact that newspapers were used not as our primary data source, but rather to augment and help minimize under-reporting operating in the historical literature is a strength of our strategy.

95. James D. Horan and Howard Swiggert, The Pinkerton Story (New York, I95 I).

96. Demarst, The River; Krause, The Battle.

97. Ibid.

98. Bruce, I877: Year of Violence.

99. Sidney Lens, The Labor Wars (New York, 1973). 
Yet we know that newspapers as a source of protest-event data are subject to two major sources of bias: (I) selectivity bias associated with kinds of events that were covered versus those ignored; and (2) description bias or the veracity of the story about events covered. ${ }^{100}$ Findings on description bias suggest that the impressions and inferences of journalists and commentators (i.e. "soft news") is a major source of multiple kinds of bias. ${ }^{\text {Ior }}$ However, we are concerned not with soft news here, but rather the "hard news" (i.e. the who, what, when, where) - how many people were killed in a strike, where, when, what industry, and who was killed by whom, if known - which tends to be quite accurately reported and mostly subject to errors of omission. ${ }^{102}$ Findings on selection bias indicate that event intensity and violence are two factors that tend to rate greater newsworthiness and hence greater likelihood of coverage, ${ }^{103}$ which bodes well for the study of strike deaths.

But even if selection bias is relatively small because of event violence, the question of stability of selection bias is important when analyzing cross-temporal patterns as we do here. Some have argued that when protest becomes institutionalized it also becomes less newsworthy, thus under-reporting and selection bias might increase. ${ }^{104}$ What does this mean for our news data? During the post-World-War-II decades, strikes most certainly became more institutionalized than in previous decades, as unions were grudgingly recognized by some employers and collective bargaining set the terms of the union contract. Strikes came to exhibit more of a contract term rhythm or periodicity. However, when killings appear in an institutionalized arena newsworthiness likely increases. This would suggest that selectivity from under-reporting is greater in the decades prior to World War II, and we should attempt to correct for that possible period differential when estimating inferential models of strike deaths in subsequent studies.

ı००. Jennifer Earl, Andrew Martin, John D. McCarthy, and Sarah Soule, "The Use of Newspaper Data in the Study of Collective Action", Annual Review of Sociology, 30 (2004), pp. $65-80$.

Ior. John D. McCarthy, Clark McPhail, Jackie Smith, and L.J. Crishock, "Electronic and Print Media Representations of Washington, DC Demonstrations, I982 and I991: A Demography of Description Bias", pp. II $3-130$ in D. Rucht, R. Koopmans, and F. Neidhardt (eds), Acts of Dissent (Lanham, MD, 1999); Earl et al., "The Use of Newspaper Data".

102. Ibid., pp. 72-73.

I03. David Snyder and William R. Kelly, "Conflict Intensity, Media Sensitivity, and the Validity of Newspaper Data", American Sociological Review, 42 (1977), pp. I05-I23; C. Mueller, "International Press Coverage of East German Protest Events, I989", American Sociological Review, 62 (1997), pp. 820-832; J. Barranco and D. Wisler, "Validity and Systematicity of Newspaper Data in Event Analysis", European Sociological Review, is (1999), pp. $30 \mathrm{I}-322$.

I04. P.E. Oliver and G.M. Maney, "Political Processes and Local Newspaper Coverage of Protest Events: From Selection Bias to Triadic Interactions", American Journal of Sociology, 106 (2000), pp. 463-505. 
The best solution for dealing with bias in protest event data collection is to rely on the triangulation of sources. ${ }^{\text {Ios }}$ The fact that we build our data base from multiple sources - historical compilations, historical case studies, and five major newspapers - is likely to greatly minimize (but not totally eliminate) sources of selectivity and under-reporting bias in the coverage of striking deaths.

\section{ANALYSIS OF STRIKING DEATH PATTERNS}

\section{The national cross-time trajectory}

Altogether I,I60 strike deaths (I,I29 (97.3 per cent) of which were within the I 877-I947 window) were identified within more than a dozen industries and across all regions of the United States during the period I870-1970. Despite being the most comprehensive count presently available, surpassing the Taft and Ross ${ }^{106}$ strike fatalities count for the same period by more than 500 deaths, the sum of recorded fatalities provided here still most certainly underestimates the overall level of lethal violence within and against the American labor movement. Such underestimation is likely due to any number of threats to accuracy outlined above, the generally conservative approach that we have taken in determining the number of fatalities during disputed incidents, and the exclusive emphasis upon strike-related fatalities that omits other forms of collective action taken by labor and capital.

The fatality data, organized in annual time-series format, are presented in Figure 3 (p. 26). As the trajectory in this figure indicates, several years into the Gilded Age the single most violent year ever recorded in American labor history occurred, the year of the Great Strike of I 877 wherein an estimated Io० individuals lost their lives. After the initial flurry of 1877 , lethal violence appears to have abated until reignited with the Haymarket bombing and other events in 1886 . Fatalities remained common to the labor movement throughout the I 890 s and Progressive Era, peaking in I 894 and again twenty years later in I9I4, the years of the tumultuous Pullman strikes and Ludlow massacre, respectively. The general upward trend that lasted from I895 through I9I4 abated during World War I. After a brief spate of fatalities immediately following the War, strike fatalities became generally uncommon before violence was again renewed during the Great Depression and New-Deal era. With the advent of World War II, strike-related violence again abated, never to return to its elevated pre-war levels.

As we suggested above, strike deaths can be taken as a tracer of major alterations in contentious collective action between capital, labor, and state. Strike fatalities are an outcome of violent contention by at least one

I05. Earl et al., "The Use of Newspaper Data", p. 74.

I06. Taft and Ross, "American Labor Violence". 


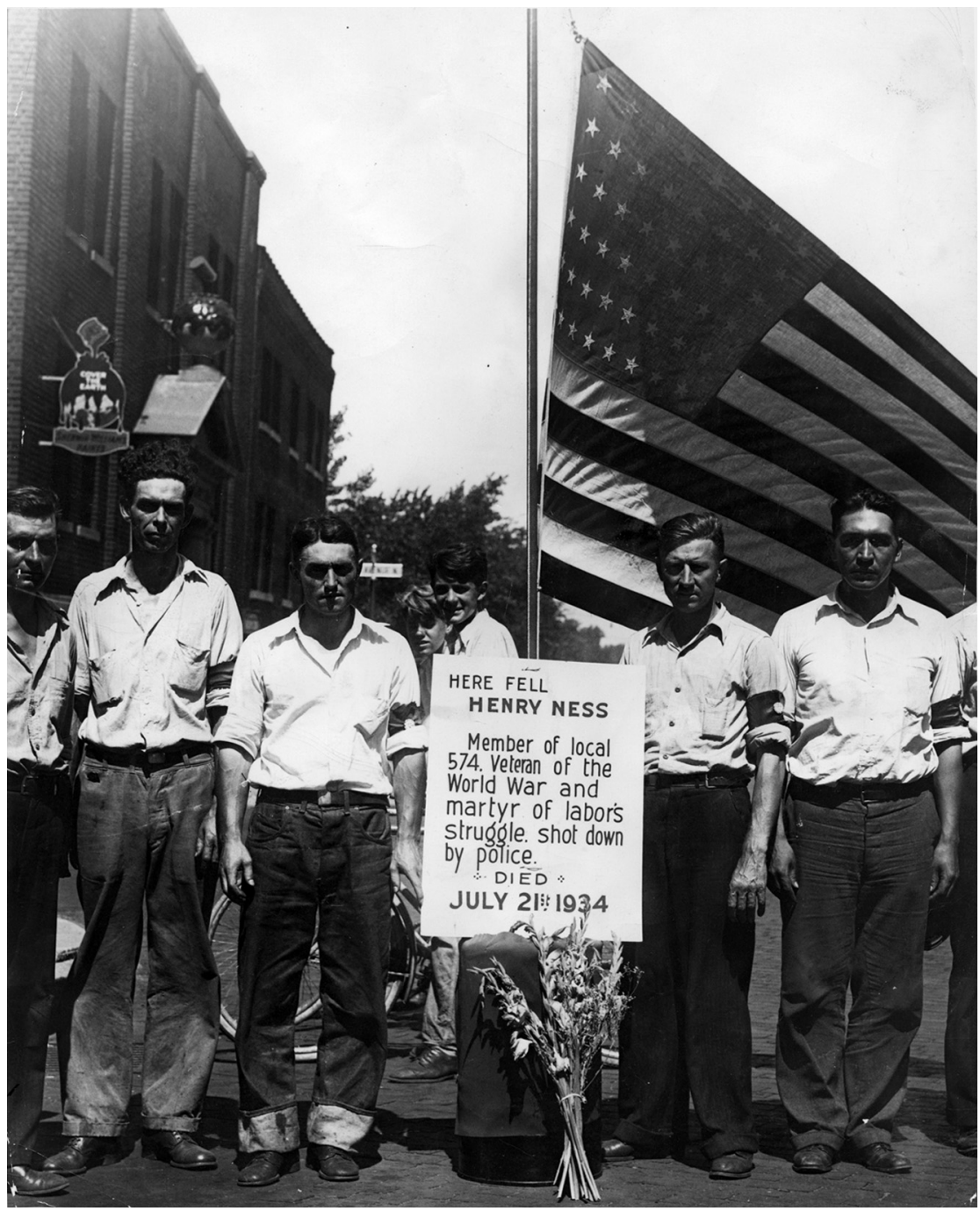

Figure I. Flag erected at the spot where Henry Ness, a striker, was killed during the Minneapolis teamsters' strike on 20 July 1934.

Minnesota Historical Society Loc\# HG3.I 8 T p40 Neg\# I I268. Used with permission.

party to a strike. It thus seems reasonable to conclude that the count of fatalities best profiles not the general contours of strike violence per se, but rather the "tip of the iceberg" or its most extreme form.

One would expect that the likelihood of lethal consequences of strikes would increase with strike frequency. Consider the ratio of strike fatalities per 100 total strikes per annum as presented in Figure 4 (p. 26). According to 


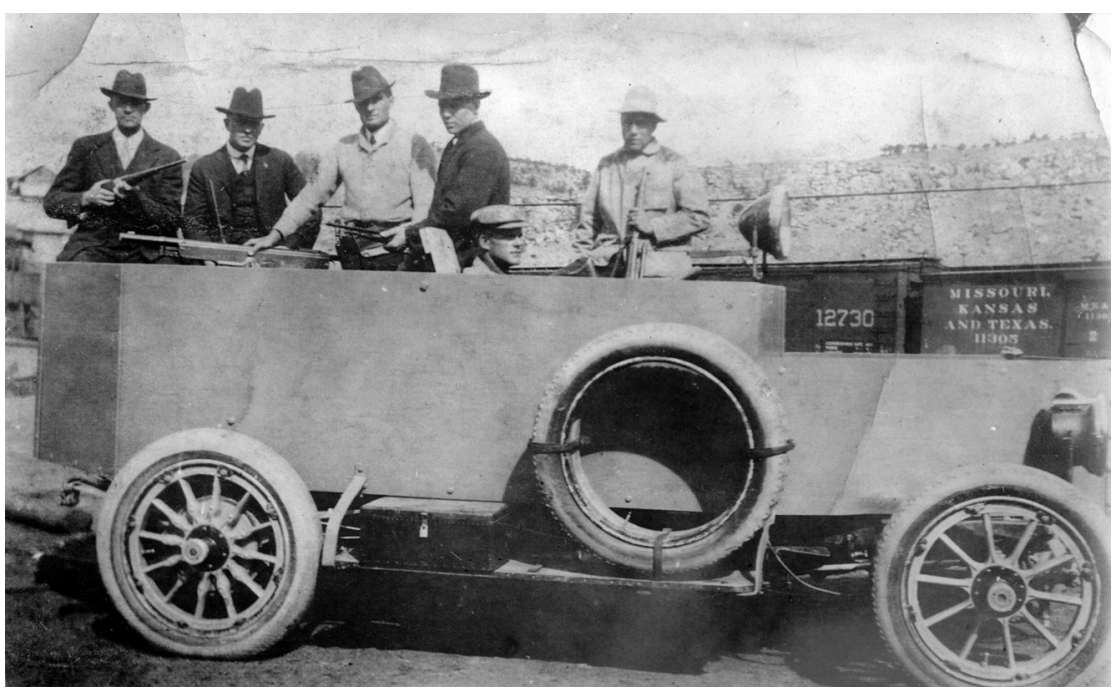

Figure 2. Baldwin-Felts detectives pose in an armored car, a.k.a., "The Death Special", used in the attack on miners during the Ludlow massacre.

Denver Public Library, Western History Collection, Call\# X-60380. Used with permission.

this measure, the likelihood of being killed on a picket line was greatest in I 877, the same year with the largest absolute number of deaths. So both absolutely and relatively speaking, I 877 constituted the most violent year between 1870 and 1970, thus deserving of its "year of violence" designation. ${ }^{107}$ Figure 5 shows deaths per 100 strikes again, but for I 880-1970, thus eliminating the scale distortion produced by 1877 . In that figure other (post-I 877) high picket line death years are more clearly revealed.

Strikes that spread from one organization, industry, or city to another sympathy, secondary, and general strikes - were often contested most vigorously by employers and the state. The correlation between years in which general strikes occurred and strike deaths is positive and rather strong $(\mathrm{r}=.446)$ over the entire period, indicating that contested vigor often resulted in greater lethal bloodshed.

On the other hand, the relationship between the number of strikes and strike deaths per year is surprisingly weak $(r=-.039)$ over the i 870-1970 period. But we detect significant changes in that relationship as we expand the temporal window from the late nineteenth century forward using a forward-moving recursive strategy. ${ }^{108}$ Figure 6 illustrates the shifting

107. Bruce, 1877: Year of Violence.

I08. For a detailed discussion of this methodological strategy, see Larry Isaac and Larry Griffin, "Ahistoricism in Time-Series Analyses of Historical Process: Critique, Redirection, and Illustrations from US Labor History”, American Sociological Review, 54 (1989), pp. 873-890. 


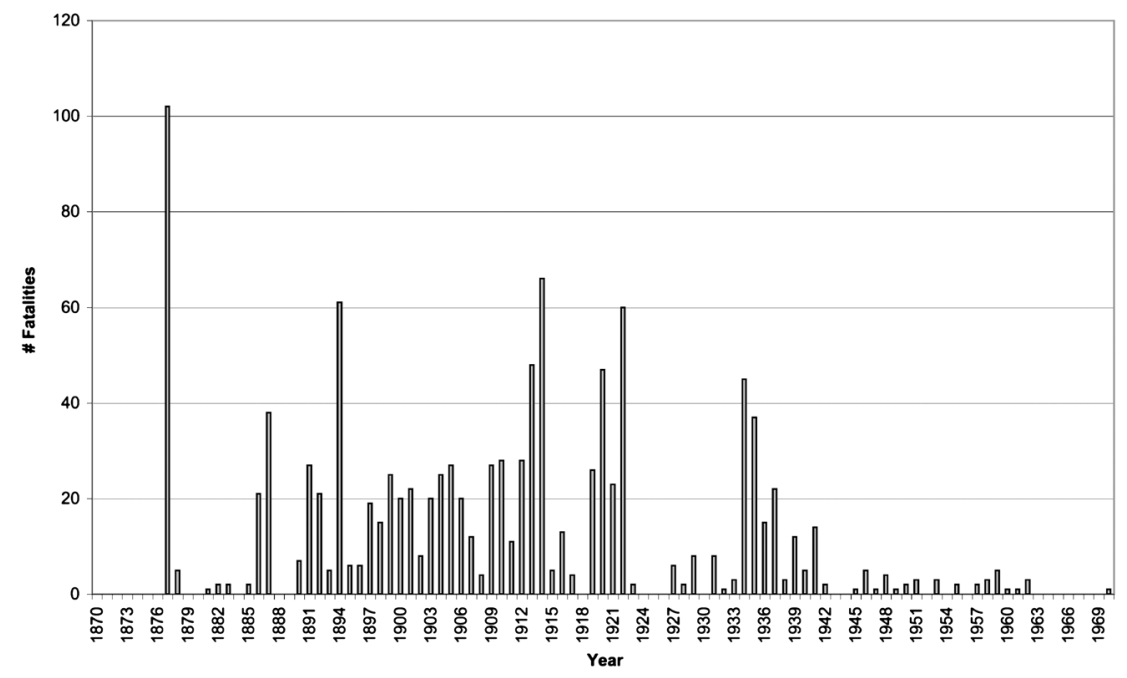

Figure 3. US strike fatalities per year, I870-1970.

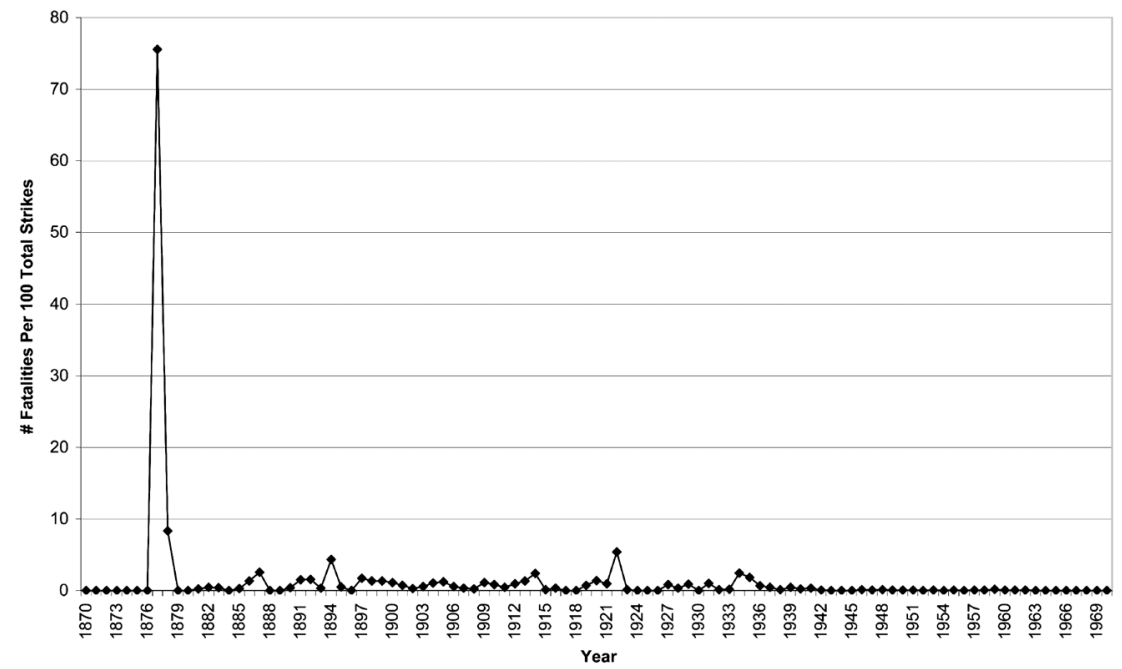

Figure 4. US strike fatalities per ioo total strikes, I870-1970.

character of this relationship, which is positive and modestly strong for the period up through the I930s, but drops off precipitously after I940, consistent with our argument about the changing legal regime governing labor and capital (more below). This suggests that it is not the sheer frequency of strikes that leads to bloodshed, but rather that frequency can 
be bloody under certain conditions, like those that prevailed prior to the juridical changes that took place between the late I930s and late I940s.

What do these national cross-temporal patterns suggest? Most fundamentally, that so many strikes were deadly in the decades between the first national-level labor strike (I877) and the New-Deal/World-War-II years indicates that this period was clearly a cultural epoch of violent

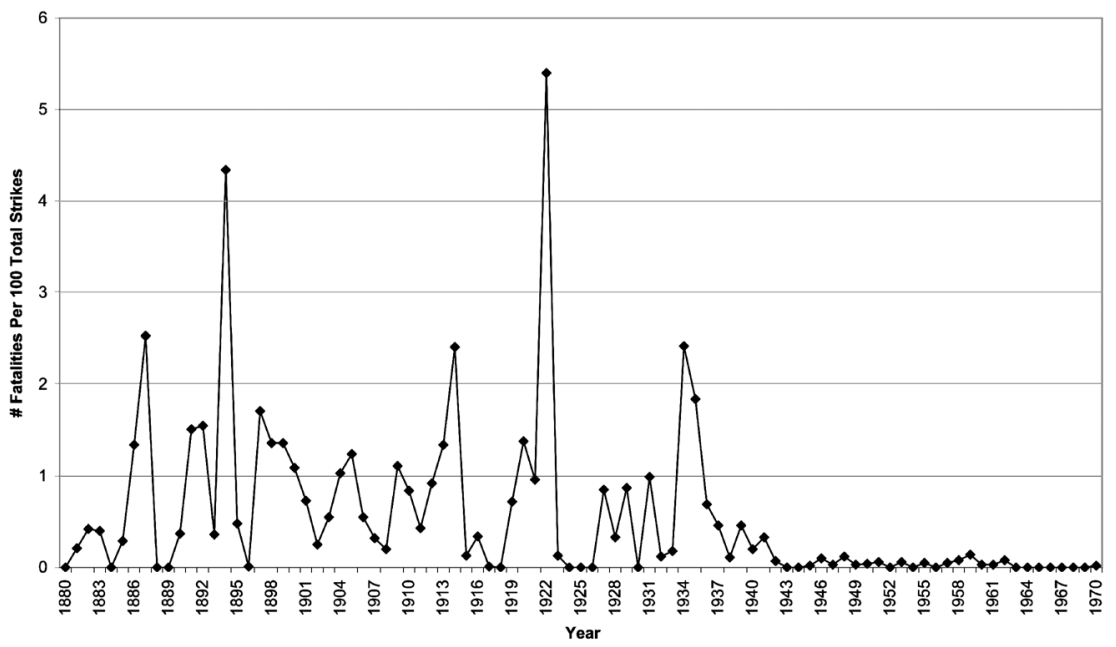

Figure 5. US strike fatalities per 100 total strikes, I880-1970.

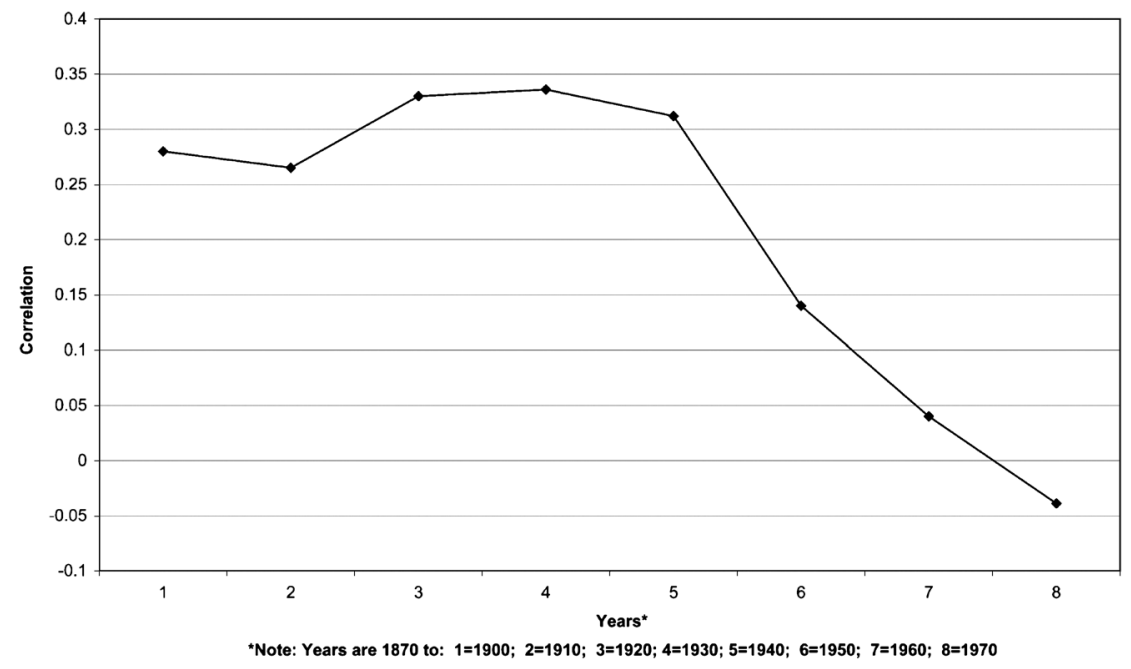

Figure 6. Relationship between strike frequency and deaths over various historical periods. 
contention between capital and labor. It was this period, covering roughly seven decades, that accounts for the exceedingly violent character of US labor-management relations. After the I940s, the number of strike fatalities plummeted to very low levels. How can we explain this major shift? What does it have to do with the exceptionalism debate?

We believe that the epoch of violent contention between capital and labor was largely a product of rather primitive markets in labor, those in which the rules and rights associated with governing workplace conflict were not well established, but were instead hotly contested. ${ }^{109}$ Where combatants came to the arena with equal claims - one with the right to consume the value of the commodity it had purchased (labor-power) as it saw fit and the other with the right to protect its value in bodily form force decides. ${ }^{\text {IO }}$ Capital with a complicit state typically held the upper hand, capable of setting the terms of labor markets on the basis of unequal force. In fact, in many local industrial areas capital was an integral part of the state's monopoly over force. ${ }^{\text {II }}$ But workers often fought back on the grounds of nothing more than broad citizenship rights which were, over much of this period, conflated with manliness; manhood was a basis for citizenship and economic activity, whether employer or employee.

So what changed during the New-Deal/World-War-II years to make US strikes less of a lethal proposition? In a word, it was a shift in legal regime governing labor-capital relations. During the epoch of violent contention, two major sources of conflict often led to violence. One was the question of union recognition, whether employers would recognize and collectively bargain with a union at all. The other was the use of replacement workers when employees did go out on strike. Between the New Deal and the end of the I940s the juridical regime governing labor-management relations shifted dramatically. Laws governing both major sources of violent contention and other labor actions changed in significant ways.

The Wagner Act, passed by Congress in 1935 and adjudicated constitutional by the Supreme Court in 1937, both empowered workers with the right to organize and to strike while simultaneously constraining those rights by defining certain types of worker collective action as illegitimate. While the right to strike was upheld in Wagner, the strike tactic itself was substantially weakened in a variety of ways specified by that Act, by several legal decisions handed down during the I940s, and ultimately in the Taft-Hartley Act of $1947 .^{\text {II }}$

I09. Tomlins, The State and the Unions.

i ı. Karl Marx, Capital, I (New York, I867/1974), p. 235.

III. Isaac, "To Counter the "Very Devil”"; Isaac, "Policing Capital”; Isaac and Harrison, "Corporate Warriors".

I I2. Holly J. McCammon, "Legal Limits on Labor Militancy: US Labor Law and the Right to Strike since the New Deal”, Social Problems, 37 (1990), pp. 206-229. 
In particular, the Wagner Act allowed employers to hire permanent replacement workers (for strikers) and also regulated the ability of unions to picket and levy union fines. ${ }^{\mathrm{II} 3}$ De jure and de facto practice during World War II fostered a quid pro quo of workers' no-strike pledge for employers' agreement to arbitrate disputes, while the sit-down strike was prohibited. With Taft-Hartley, labor lost some of the most effective tactics in its collective action repertoire - closed shops, jurisdictional strikes, wildcat strikes, recognition strikes where a previously certified union was in place, sympathy/secondary boycotts and picketing, ${ }^{\text {II } 4}$ and by extension, the general strike.

Strikes certainly did not disappear after changes in the labor-law regime established between the Wagner and Taft-Hartley Acts. In fact, the average annual strike frequency between I9I4 and I930 was 2, I 46.5, while the figure for 1950-I 970 was virtually double at 4,249.I. ${ }^{\text {II } 5}$ But since that legal change, labor law has selectively restricted the forms of strike activity that most effectively challenged employer authority at work. ${ }^{116}$ This is reflected in the frequency of general strikes and union recognition strikes in the eras before and after the legal regime change. Between I 877 and 1930, ten major general strikes occurred and the proportion of total strikes initiated over primarily union recognition was 23 per cent; parallel figures for the postwar era (1950-1970) are zero and I 2 per cent.

The fact that all forms of strike activity were substantially more politicized and contentious during the era before the New Deal is apparent in the relationship between deaths, issue-specific strikes (wage, union recognition) and general strikes both before and after the legal regime change (shown in Table I overleaf). General strikes, union recognition, and wage strikes are all positively related to strike deaths in the pre-NewDeal era. During the postwar decades, only union recognition strikes are positively, but much more weakly, related to deaths; wage strikes are weak and inversely related to deaths, and general strikes ceased to exist.

While granting de jure recognition to union organization and the strike, labor law since the New Deal simultaneously undermined workers' collective power by constraining the use of the strike. ${ }^{I 7}$ A byproduct of this legal legitimation by the state, however unequal in class terms,

II3. Ibid., p. 2 I 2.

I 4 . Ibid.

I I 5. There is also evidence that new mass movements during the postwar decades (e.g. civil rights, antiwar, women's) stimulated strikes and unionization, especially in the public sector; see Larry Isaac and Lars Christiansen, "How the Civil Rights Movement Revitalized Labor Militancy", American Sociological Review, 67 (2002), pp. 722-746; Larry Isaac, Steve McDonald, and Greg Lukasik, “Takin' it from the Streets: How the Sixties Mass Movement Revitalized Unionization", American Journal of Sociology, i I 2 (2006), pp. 46-96.

i 16. McCammon, "Legal Limits on Labor Militancy".

I 17. Ibid., p. 223. 
Table I. Relationship between strike deaths and forms of strikes, by bistorical period co-variance (correlation)

\begin{tabular}{lcc}
\hline & Pre-New Deal (1880-1930) & Post-WWII (1950-1970) \\
\hline Wage strikes & $3709.7(.31)$ & $-74.9(-.10)$ \\
Union recognition strikes & $2519.1(.32)$ & $62.5(.34)$ \\
General strikes & $3.7(.41)$ & $0 \#$ \\
\hline
\end{tabular}

Note: General strike data are from L. Isaac, D. Harrison, and P. Lipold, "Class Conflict", pp. 275-295 in Lester Kurtz (ed.), Encyclopedia of Violence, Peace, and Conflict, 2nd edn (Oxford, 2008); wage and union recognition strikes are from US Bureau of the Census (1975), Historical Statistics of the United States, and US Bureau of Labor Statistics, Analysis of Work Stoppages, various years. Union recognition and wage strikes were not reported for the years I906-19I3, and were estimated by the authors using linear interpolation.

\# No general strikes occurred during the postwar decades.

contributed substantially to the reduction in lethal violence between capital and labor. By outlawing the most effective forms of collective action deployed historically by the labor movement and aggressively confronted by capital - e.g. sympathy strikes, general strikes, wildcat strikes, sit-down strikes - and grounding employers' right to hire permanent replacement workers in the law, the new juridical regime not only weakened labor relative to capital but also diminished the level of lethal violence associated with strikes. As such, the regulation of labor power shifted from direct physical coercion to legally based consent - the joint agreement that confrontation over grievances was better settled by the National Labor Relations Board than in the streets - and in the process hegemony replaced naked force. The fact that the US state would cling to a strong laissez-faire position on markets for so long, letting capital and labor contention take its often bloody path, is likely a major factor in explaining much of what is exceptional about the trajectory of class relations in American history.

\section{Inter-industry comparisons}

The history of strike mortality also displays considerable inter-industry variation. We find that lethal violence was most heavily concentrated within the extraction and transportation sectors. The coal-mining industry alone, for instance, accounted for roughly one-third (34.3 per cent) of all recorded strike fatalities, while the 199 deaths attributed to the railroads constituted another I 8.I per cent. Yet there was a notable difference between the two. Labor violence within the mines paused at length only for cause of war, while deaths in the rail industry were more episodic. The bulk of violence along the railways was concentrated within 
four particular years - seeming to suggest that the explosions of violence in 1877, I 894, I9II, and 1922 resulted in temporary resolutions of labor strife or otherwise stretches of relative peace.

The cross-temporal trend in strike fatalities is downward over the I $870-1970$ period, and that is generally reflected within industrial sectors shown in Table 2 overleaf as well. However, transportation is the only sector that followed a strictly monotonic decline. All the others show trajectories with moderate reversals to trend at least once over the full temporal window. Manufacturing is a case in point. After falling to eighteen deaths in the I920s, the body count jumped to sixty-nine during the Great Depression decade as the industrial workers' movement fought for union recognition in the mass-production industries like steel, rubber, electrical equipment, and automobiles. ${ }^{\text {II } 8}$

Some of the raw comparisons may simply seem counter-intuitive. For instance, agriculture and food processing experienced similar levels of lethal violence as recorded in the steel industry. In fact, the entire manufacturing sector accounted for slightly less than i 9 per cent of all fatalities. The teamsters and longshoremen, too, were notoriously violent, or at least so popularly portrayed. Yet they constituted a relatively minor fraction herein. Fifty-seven deaths were attributed to teamster strikes, while fifty-six deaths were reported along the docks, comprising 3.5 per cent and 5.I per cent of the overall total, respectively. Construction, too, was surprisingly low, given the popular image of the scrappy, rugged building trades worker. The entire construction sector accounted for only I.4 per cent of strike-related deaths between I 877 and I 947 . However, the lowest level of violence was found within the service and retail industries, posting a combined total of seven deaths, or only about 0.6 per cent of the total.

While we believe that the New-Deal/World-War-II shift in legal regime governing labor-management relations was responsible for the rapid decline in the lethal character of strikes after World War II, other factors were also undoubtedly involved as well. This is signaled in the declining death trend revealed in several industrial sectors. A variety of gradually changing social conditions likely contributed to these downward trends, including changes in life expectancy and related perceptions regarding mortality and improvements in medical technologies and delivery that would allow some injured in strikes to survive their injuries which may have earlier claimed their lives.

What of the substantially more lethal quality of strikes in the extraction and transportation industries? More than 80 per cent of the strike deaths between I870 and I947 took place in these two industrial sectors. 


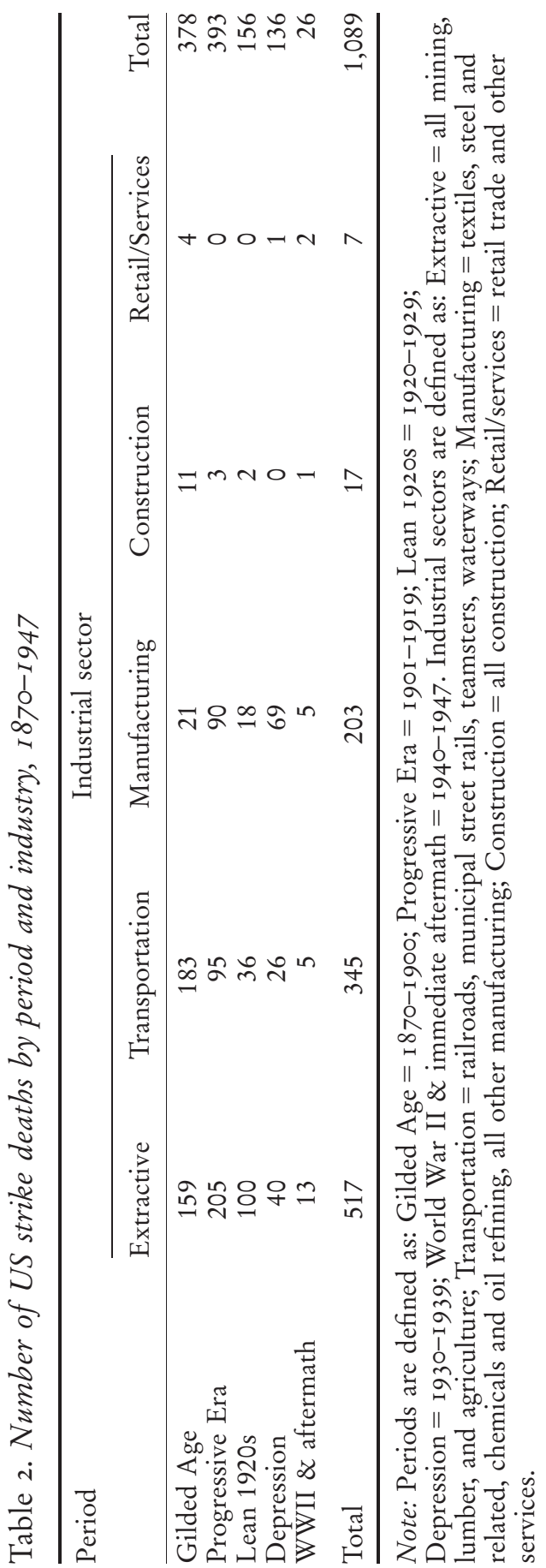


Extraction (e.g. mining) and transportation (e.g. rails) were both leading economic sectors during America's economic take-off. As such, it was in these locations that many of the early battles for union recognition took place. Moreover, the fact that they were leading economic sectors upon which so many other industries depended would have also meant that work stoppages could be more costly, not only to immediate strike targets, but to economic interests further downstream. Thus, employers and state agents may have fought more aggressively (and more lethally) to break strikes in those sectors, consistent with social-movement studies that find a positive correlation between the magnitude of threat and corresponding repression. ${ }^{\text {II9 }}$ At a minimum, Table 2 indicates that strike deaths did not occur smoothly, evenly over time or across industry. This means that industry will likely be important in deciphering the meaning of striking deaths in the American workplace.

\section{Victim and killer status}

In historical and press sources, information is often not provided for status of victim or killer in reports of deadly strikes. Specific contextual information such as the duration, size, and goals of the strikes and tactics, affiliation, or ethnicity of the participants are also frequently unavailable. Nevertheless, sufficient details exist regarding the status categories of individuals killed and those of killer to make some worthwhile comparisons.

For the period between I 877 and I947, 602 ( 53.3 per cent) of the total strike fatalities could be categorized by victim status with a reasonable degree of confidence. These fatalities are reported by victim characteristics in Table 3 overleaf. Of these, 385 (64 per cent) were strikers, picketers, labor organizers, or unaffiliated sympathizers; 7I ( I I.8 per cent) were strike-breakers and/or non-strikers; 36 (6.0 per cent) were either company guards or private agents hired by the company; 37 (6.I per cent) were either federal, state, or local level law-enforcement agents; 6I (IO.I per cent) were either innocent bystanders or otherwise unintentional participants; and I2 (2.I per cent) were either company executives or government officials. If we assume that "bystanders" and "company guards and hired agents" were typically working-class people, then clearly the vast majority of strike casualties (9I.9 per cent) were inflicted on the working class. Capitalist and state agents were only infrequently (8.2 per cent) the victims of strike violence.

We were also able to recover the status of killer for 636 deaths. Here we found a slightly larger array of death-dealing actors - state agents (e.g. police, militia, National Guard, Army), hired company agents (e.g.

I 19. See Jennifer Earl, “Tanks, Tear Gas, and Taxes: Towards a Theory of Movement Repression”, Sociological Theory, 2 I (2003), pp. 44-68. 
Table 3. Victim and killer status in strike deaths, I870-1947

\begin{tabular}{|c|c|c|c|c|c|}
\hline Victim status & $\mathrm{N}$ & $\%$ & Killer status & $\mathrm{N}$ & $\%$ \\
\hline $\begin{array}{l}\text { Striker, labor organizer, } \\
\text { sympathizer }\end{array}$ & 385 & 64.0 & State agent & 329 & 51.7 \\
\hline $\begin{array}{l}\text { Strike-breakers and/or non- } \\
\text { union workers }\end{array}$ & 71 & 11.8 & Hired company agent & 72 & 11.3 \\
\hline Bystanders & 61 & 10.1 & Striker & 94 & 14.8 \\
\hline $\begin{array}{l}\text { Company guards or hired } \\
\text { agents }\end{array}$ & 36 & 6.0 & Strike-breakers & 49 & 7.7 \\
\hline $\begin{array}{l}\text { Federal, state, or local law } \\
\text { enforcement agents }\end{array}$ & 37 & 6.1 & Vigilantes & 66 & 10.4 \\
\hline \multirow{3}{*}{$\begin{array}{l}\text { Company executives or } \\
\text { government officials }\end{array}$} & 12 & 2.1 & Union officials & 20 & 3.1 \\
\hline & & & Gangsters & 1 & 0.2 \\
\hline & & & Employers & 5 & 0.8 \\
\hline Total & 602 & 100.0 & & 636 & 100.0 \\
\hline
\end{tabular}

Note: For the years I 870-I947, only 5 I.7 per cent of the total strike fatalities over the period could be categorized by victim status and only 54.8 per cent for killer status with reasonable confidence.

company guards, Pinkertons), strikers, strike-breakers, vigilantes, union officials, ${ }^{120}$ gangsters, and employers. On balance, our data indicate that the vast majority of strike deaths were suffered by strikers (or their sympathizers) and the overwhelming majority of death was produced by state agents. The picture is substantially more uneven if we aggregate known killers according to labor-movement actors (strikers and union officials) and counter-movement actors (state agents, company agents, strike-breakers, vigilantes, gangsters, employers), which indicates that I7.9 per cent of the known killings were at the hands of labor-movement actors while 82.I per cent was due to counter-movement forces. American workers sometimes resorted to violence, but were far less likely to inflict lethal violence than were the forces arrayed against them.

\section{Regional patterns}

The geographical location of the events has been more comprehensively recorded. Table 4 shows the distribution of strike deaths by historical period and region. In fact, the state in which the individual fatalities occurred has been recorded for I,073 (92.4 per cent) of the I, I60 total recorded victims, and includes a total of 38 states and the District of

I 20. The twenty deaths due to union officials come from one event - the bombing of the Los Angeles Times building by AFL officials in I910; see Louis Adamic, Episodes of Violence in US History, I: Dynamite (New York, 1983). 
Table 4. Number of US strike deaths by period and region, I870-1970

\begin{tabular}{lcrrrrr}
\hline Period & \multicolumn{5}{c}{ Region } & \\
\cline { 2 - 5 } & Northeast & Midwest & West & South & Total & Annual Average \\
\hline Gilded Age & 124 & 114 & 43 & 78 & 359 & 15.0 \\
Progressive Era & 76 & 61 & 164 & 79 & 380 & 20.0 \\
Lean 1920s & 10 & 27 & 18 & 79 & 134 & 13.4 \\
Depression & 22 & 42 & 18 & $\mathbf{6 2}$ & 144 & 14.4 \\
WWII \& aftermath & 3 & 4 & 2 & 16 & 25 & 3.1 \\
Post-WWII & 3 & 4 & 0 & 24 & 31 & 1.3 \\
Golden Years & 238 & 252 & 245 & 338 & $1073 *$ & \\
Total & & & & & &
\end{tabular}

Note: Region is defined by current four-region US Bureau of the Census categories; see: http://www.fedstats.gov/qf/; Northeast = ME, VT, NH, CT, MA, RI, NY, NJ, PA; Midwest $=\mathrm{OH}$, MI, IN, IL, WI, IL, MO, IA, MN, ND, SD, NE, KS; West = WA, OR, CA, ID, NV, UT, AZ, MT, WY, CO, NM; South = TX, OK, AR, LA, MS, AL, GA, FL, KY, TN, WV, VA, MY, DE, DC, NC, SC. Periods are defined as: Gilded Age = 1870-1900; Progressive Era = I90I-I919; Lean I920s = I920-I929; Depression = I930-I939; World War II and aftermath = I940-I947; Post-WW-II Golden Years $=$ I948-1970.

*Note: The difference in total $\mathrm{N}$ in this table $(\mathrm{I}, 073)$ and that of Table $2(\mathrm{I}, 089)$ is due to lack of detail on some events disallowing categorization by region or industry, and to the longer temporal window used in this table.

Columbia. Not surprisingly, mining states such as Pennsylvania, Colorado, West Virginia, Alabama, and Kentucky were among the most violent by the occurrence of strike deaths. Industrial states such as Illinois, Indiana, Ohio, New York, and Missouri were also quite heavily represented. But perhaps most surprising - likely because of images of violent confrontations associated with the most highly industrialized areas of the northern US - is the South. By the I920s, the southern region became the leader in lethal strike victims and continues to lead for all subsequent periods. In fact, the southern region was host to roughly 30 per cent of the strike-related deaths in the US during the century from I 870 to I970.

What was behind the regional unevenness in lethal strikes? We can only speculate with the data at hand, but this may be indicative of different cultures of class (and life) de-valorization. In the early decades of the labor movement, much of the strike-related death was associated with industries populated by recent immigrant labor - mining and various modes of transportation, like rails. A somewhat different version of labor de-valorization existed in the South under the Jim Crow regime which subjugated black and much poor white labor to highly oppressive conditions and the lack of citizenship rights. Cultural contexts within which certain lives are grossly devalued are likely to lead to higher levels of mortality when workplace issues become particularly contentious. The fact that the South 
experienced relatively stable strike-mortality levels across historical periods and led all regions in strike deaths from the I920s forward (see Table 4) may also indicate the influence of regional uneven development - the South industrialized later than other regions of the country.

The regional variation revealed in Table 4 is consistent with the arguments of those who have advanced calls for a comparative regional perspective in studies of American exceptionalism. ${ }^{\text {III }}$ The fact that the South led in the number of strike deaths from the I920s through the I960s is indicative of just how blatantly coercive labor markets were in that region prior to the southern civil rights movement that crested between the midI950s and mid-I960s. Very much part of the US exceptionalism question, "southern exceptionalism" was put in place by the I890s as "disenfranchisement freed southern politicians to act as agents of capital against labor. Nowhere else in the United States did state officials work so closely with employers against labor". ${ }^{22}$ Others have pointed to unique features of contentious industrial relations in the West, harsh treatment of specific workers (e.g. immigrants and American Indians), ${ }^{{ }^{23}}$ and the relatively weak state that allowed for a variety of exceptional employer harshness in treatment of workers. ${ }^{\mathrm{I} 4}$ This within-nation variation is important for coming to terms with the meaning of exceptionalism.

\section{CONCLUSIONS AND NEW DIRECTIONS}

We have argued that violence, especially in lethal form, provides an important signal about the character of collective contention generally and a very important dimension of the American labor movement for much of its history. But we have shown that the historical literature, while rich in insights and indispensible to our project, provides a view of lethal violence deployed during US strike activity which is fragmentary at best. Endeavoring to get beyond such a fragmentary picture, we have followed a more systematic approach to collecting and analyzing strike mortality data.

I 2 I. For example, see Gerald Friedman, "The Political Economy of Early Southern Unionism: Race, Politics, and Labor in the South, I880-1953", Journal of Economic History 60 (2000), pp. 384-4I 3; David Igler, "The Industrial Far West: Region and Nation in the Late Nineteenth Century", Pacific Historical Review, 69 (2000), pp. I 59-192; Andrew Yarmie, "Employers and Exceptionalism: A Cross Border comparison of Washington State and British Columbia, I 890-1935", Pacific Historical Review, 72 (2003), pp. 56I-6I 5.

I 22. Friedman, "The Political Economy of Early Southern Unionism", p. 407; see also S.B. Greenberg, Race and State in Capitalist Development (New Haven, CT, 1980); M. Goldfield, "Class, Race, and Politics in the United States", Research in Political Economy, I 2 (1990), pp. 83-I 27; Rick Halpern, "Solving the Labor Problem: Race, Work, and the State in the Sugar Industries of Louisiana and Natal, I870-1910," Journal of Southern African Studies, 30 (2004), pp. 19-40.

I 23. Igler, "The Industrial Far West".

I24. Yarmie, "Employers and Exceptionalism". 
Our goal here was to provide the conceptual warrant for such an analysis, along with a detailed description of our methodological strategy and basic empirical patterns of striking deaths that these strategies revealed. Systematically collected data has allowed us to offer the first broad overview of deadly strikes in the United States, or any country for that matter. The enormous volume of deadly events, their timing, geographical location, and killer and victim configurations should figure significantly in any debate about American exceptionalism and comparative strike studies. If America was truly exceptional in the amount of deadly force brought to bear in the face of its labor movement, then within-country exceptions in time, region, industry, and victim characteristics should be unpacked and play a role alongside cross-national comparative data. For it is in both within-country and between-country variations that we are ultimately likely to find a more satisfying assessment of the exceptionalism question.

US strikes were especially likely to be lethal in the era between the late I 870 s and late I940s. The fact that the US state took a stance that favored capital during these decades, and did so by being complicit in the bloodshed, and only during the New-Deal/World-War-II years shifted its juridical climate governing labor-capital contention explains both the decline in deadly strikes and the basis for the quite likely bloody exceptionalism in US labor history. ${ }^{125}$ Deadly strikes occurred across all regions of the country and all industrial sectors, but did so unevenly. Region and industry mattered; being involved in a strike in a southern extractive industry (e.g. agriculture or mining) could be especially dangerous during these decades. Although we were unable systematically to acquire comprehensive racial information on strike-death victims, it is very likely that being a black striker in any industry within the southern region of the country would have been potentially a very deadly proposition.

We have concentrated on mortality inflicted during the course of a labor strike, a limited but nonetheless important dimension of labor repression. But labor movements in the US sometimes met with bloody assaults, even when not striking. For example, in addition to the more than $\mathrm{I}, 000$ strike deaths discussed above, we have compiled data on another 240 deaths that occurred in non-strike labor actions between 1916 and 194I. The vast majority of these victims were either African-American and/or IWW members, suggesting that particular characteristics of labor activists (e.g. race and movement ideology) made the struggle more treacherous for some than for others. To be both black and "red" (i.e. non-white and leftist), for instance, was to be truly a high-risk activist in movement context.

I 25. We say "quite likely" because, while we believe that the US union movement encountered more lethal violence than movements in other nations over the same historical period, systematic data has yet to emerge for such empirical comparisons. 
What additional questions might these data allow us to address in subsequent studies? There are four in particular that we think most significant. First, What are the social, political, and economic conditions that shape the volume of strike-related mortality over time, space, and industry? We have suggested several major macro changes that may have been jointly responsible for extinguishing much of the lethal quality of strikes in America by the late I940s. But strike deaths fluctuated from year to year in addition to following a long-term declining trend. How do we explain the short-term variations in strike deaths? Our data will permit pioneering analyses of the social factors that account for temporal, spatial, and industrial variations in strike mortality. The preliminary data reported in this paper indicate how important time, geographical place, and industry were to shaping strike deaths.

Second, How did patterns of killer-victim statuses vary across time, industry, and region? The aggregate data presented here indicate that all major parties to strikes - labor, employers, state - were involved in bloodshed, albeit unevenly. Our data will allow a more detailed view of killer-victim status by historical period, geographical location, and industry. Such analyses will provide important clues about dynamics of and insights into how lethal repression varied in systematic ways that may provide new leverage on questions about the role of employers and the state in weakening various portions of the US labor movement.

Third, What impact, if any, did temporal variations in strike deaths have on the fortunes of the American labor movement? Our data will allow an examination of strike deaths as an independent variable in models of labor unionization across time nationally, across time by industry, and across space. It is now feasible to examine direct bloodshed as a factor of contention along with other dimensions of labor-movement repression, such as the use of court injunctions against strikers, ${ }^{\mathrm{I} 26}$ or the mobilization of anti-union counter-movement organizations like the National Association of Manufacturers, ${ }^{\mathrm{I} 27}$ or the use of strike-breakers. ${ }^{\mathrm{I} 28}$ The availability of strike-mortality data will allow us to come closer to elaborating fully the multi-dimensional character of repression ${ }^{\mathrm{I} 29}$ which the American labor movement faced over the late nineteenth century through much of the twentieth century, and to estimate the separate and combined effects of the various dimensions.

Finally, How do these US patterns of bloody strikes compare with those of other countries? As we indicated at the outset, a number of scholars

I26. McCammon, “'Government by Injunction'”.

I 27. Griffin et al., "Capitalist Resistance".

I 28. Whatley, "African American Strikebreaking".

I29. For a detailed conceptual model of the mechanisms of state repression operating against challenging social movements, like labor, in the United States, see Boykoff, "Limiting Dissent". 
have claimed that repression of labor in contention with capital was part of a configuration of American exceptionalism - i.e. that America was a deviant case, at least among other Western democratic, industrial nations, and heavy repression of labor was part of what made America an unusual case. Our data coupled with unsystematic reports from other scholars Gitelman on France ${ }^{130}$ and Sexton on Britain ${ }^{131}$ - does offer prima facie evidence that the US labor movement was forged in a relatively more lethal climate. Comparative unionization and strike studies indicate possible cross-national convergence with recent declines in union density for some European countries. ${ }^{132}$ This may mean that even the most generous interpretations of evidence in support of American exceptionalism should be careful to place bounds on the scope of the meaning of the term - when, where (region and industry), and in what ways did exceptionalism appear relative to other nations? We have established the groundwork to do that for lethal strike violence.

Until we have comparable, systematic cross-national over time data on dimensions like strike violence, one can do little more than speculate. We hope that our efforts will motivate others to collect mortality data associated with strikes in other countries. This would provide a new and important dimension to comparative strike studies and offer new leverage on the exceptionalism debate. While such data from any country would be a welcome addition, it would be especially helpful to have comparative data from continental European countries. ${ }^{133}$ Only when we have such comparative between-nation and within-nation micro data presented here will we be able to directly address in a systematic comparative fashion claims that the American labor movement was exceptional because of the bloody path it experienced.

I30. Gitelman, "Perspectives on American Violence".

I3 I. Sexton, The War on Labor.

I32. See Oliver Blanchard, "The Economic Future of Europe", Journal of Economic Perspectives, I8 (2004), pp. 3-26; Larry W. Isaac, Daniel M. Harrison, and Paul F. Lipold, "Class Conflict in Capitalist Society", in Lester Kurtz (ed.), Encyclopedia of Violence, Peace, and Conflict, 2nd edn (Oxford, 2008), pp. 275-295.

133. Kirk, "Peculiarities versus 'Exceptionalism"”; Kreuzer, "Parliamentarianization and the Question of German Exceptionalism”. 